\title{
Synergies between biodiversity conservation and ecosystem service provision: Lessons on integrated ecosystem service valuation from a Himalayan protected area, Nepal
}

Kelvin S.-H. Peh ${ }^{\mathrm{a}, \mathrm{b}}$, , Ishana Thapa $^{\mathrm{c}}$, Menuka Basnyat ${ }^{\mathrm{c}}$, Andrew Balmford ${ }^{\mathrm{b}}$, Gopal Prakash Bhattarai $^{\text {d }}$, Richard B. Bradbury ${ }^{\text {b, e, f }}$, Claire Brown ${ }^{\mathrm{g}}$, Stuart H. M. Butchart ${ }^{\mathrm{b}, \mathrm{h}}$, Maheshwar Dhakal $^{\mathrm{d}}$, Hum Gurung ${ }^{\mathrm{c},-\mathrm{i}}$, Francine M. R. Hughes ${ }^{\mathrm{j}}$, Mark Mulligan ${ }^{\mathrm{k}}$, Bhopal Pandeya ${ }^{\mathrm{k}, 1}$, Alison J. Stattersfield $^{\mathrm{h}}$, David H. L. Thomas ${ }^{\mathrm{h}}$, Matt Walpole ${ }^{\mathrm{g}}$ and Jennifer C. Merriman ${ }^{\mathrm{h}}$

${ }^{\mathrm{a}}$ Centre for Biological Sciences, University of Southampton, University Road, Southampton S017 1BJ, UK

${ }^{\mathrm{b}}$ Conservation Science Group, Department of Zoology, University of Cambridge, Downing Street, Cambridge CB2 3EJ, UK

${ }^{\mathrm{c}}$ Bird Conservation Nepal, P.O. Box 12465, Kathmandu, Nepal

${ }^{\mathrm{d}}$ Department of National Parks and Wildlife Conservation, G.P.O. Box 860, Babarmahal, Nepal ${ }^{\mathrm{e}}$ RSPB Centre for Conservation Science, Royal Society for the Protection of Birds, Sandy, SG19 2DL, UK

${ }^{\mathrm{f}}$ RSPB Centre for Conservation Science, The David Attenborough Building, Pembroke Street, Cambridge CB2 3QZ, UK

${ }^{\mathrm{g}}$ United Nations Environment Programme World Conservation Monitoring Centre, Cambridge CB3 0EL, UK

${ }^{\mathrm{h}}$ BirdLife International, The David Attenborough Building, Pembroke Street, Cambridge, CB2 3QZ, UK

${ }^{\mathrm{i} B i r d L i f e}$ International Asia, Tanglin International Centre, Tanglin Road, S274672, Singapore.

${ }^{\mathrm{j}}$ Animal and Environment Research Group, Department of Life Sciences, Anglia Ruskin University, Cambridge CB1 1PT, UK

${ }^{k}$ Department of Geography, Kings College London, London WC2R 2LS, UK 
${ }^{\text {l} G r a n t h a m ~ I n s t i t u t e ~ f o r ~ C l i m a t e ~ C h a n g e ~ a n d ~ t h e ~ E n v i r o n m e n t, ~ I m p e r i a l ~ C o l l e g e ~ L o n d o n, ~ S o u t h ~}$ Kensington Campus, London SW7 2AZ, UK

*Corresponding author at: Centre for Biological Sciences, University of Southampton, University Road, Southampton S017 1BJ, UK;

Email: kelvin.peh@gmail.com (K.S.-H. Peh) 


\section{Keywords}

Alternative state; decision-making; integrated valuation; rapid assessment; trade-off; TESSA

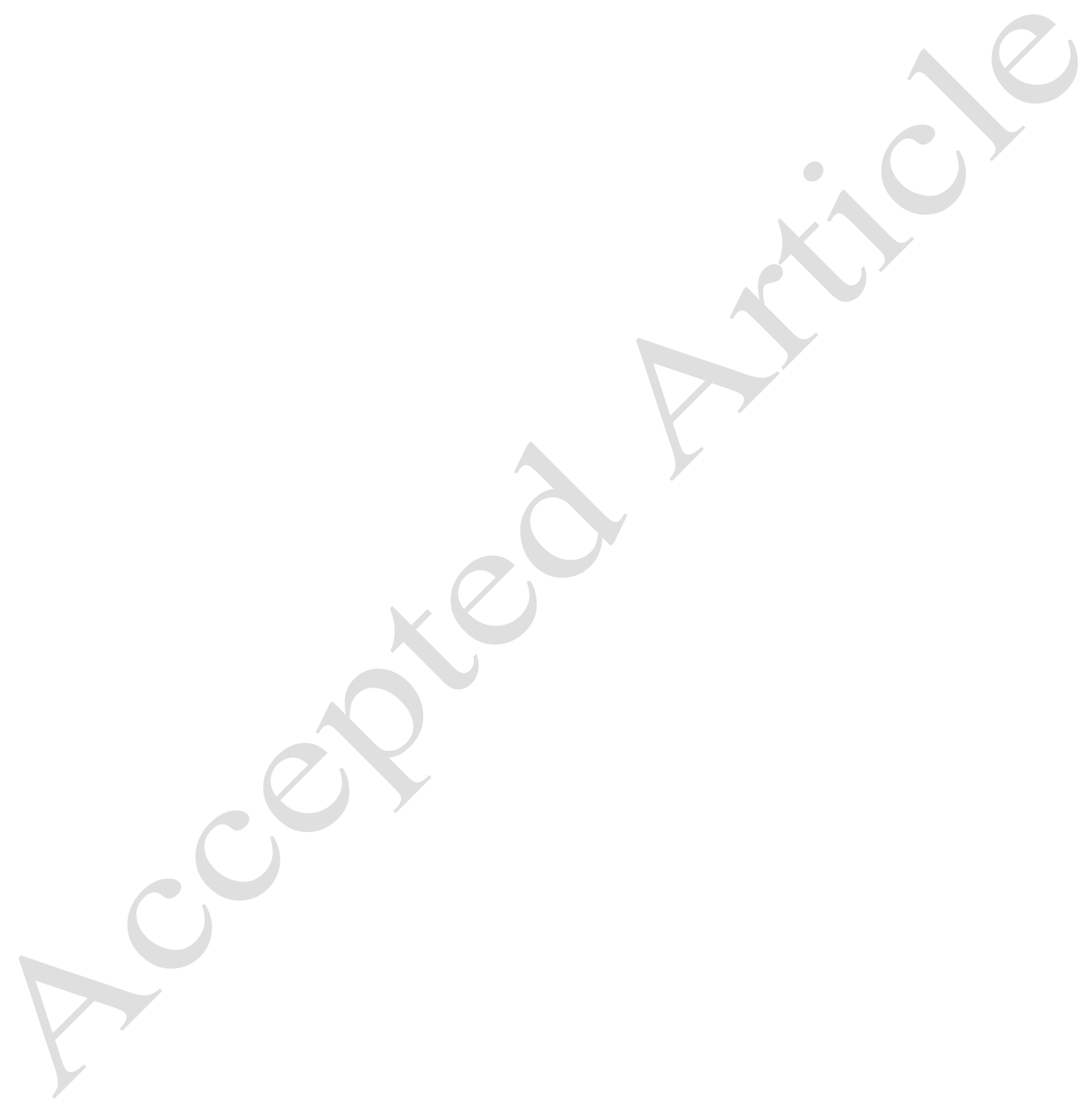




\begin{abstract}
We utilised a practical approach to integrated ecosystem service valuation to inform decisionmaking at Shivapuri-Nagarjun National Park in Nepal. The Toolkit for Ecosystem Service Sitebased Assessment (TESSA) was used to compare ecosystem services between two alternative states of the site (protection or lack of protection with consequent changed land use) to estimate the net consequences of protection. We estimated that lack of protection would have substantially reduced the annual ecosystem service flow, including a $74 \%$ reduction in the value of greenhouse gas sequestration, $60 \%$ reduction in carbon storage, $94 \%$ reduction in nature-based recreation, and $88 \%$ reduction in water quality. The net monetary benefit of the park was estimated at $\$ 11$ million year ${ }^{-1}$. We conclude that: (1) simplified cost-benefit analysis between alternative states can be usefully employed to determine the ecosystem service consequences of land-use change, but monetary benefits should be subject to additional sensitivity analysis; (2) both biophysical indicators and monetary values can be standardised using rose plots, to illustrate the magnitude of synergies and trade-offs among the services; and (3) continued biodiversity protection measures can preserve carbon stock, although the benefit of doing so remains virtual unless an effective governance option is established to realise the monetary values.
\end{abstract}

\title{
Highlights
}

- TESSA was used for integrated ecosystem services valuation of Shivapuri-Nagarjun National Park, Nepal.

- Net monetary ecosystem service value of protecting the Park was estimated at $\$ 11$ million $\mathrm{y}^{-1}$.

- Protection avoided a reduction in carbon stock of $60 \%$ and a net annual monetary loss of $19 \%$.

- Conservation and ecosystem service provision objectives were congruent at site-level.

- A buffer zone around the park may improve benefit sharing. 


\section{Introduction}

For centuries, protected areas (PAs) have played a fundamental role in the conservation of biodiversity and ecosystems (Juffe-Bignoli 2014; Mascia et al. 2014; Palomo et al. 2014). Conservationists have argued for the designation and effective management of PAs and for the protection of critical sites for biodiversity - such as Important Bird and Biodiversity Areas (IBAs; BirdLife International 2014), Alliance for Zero Extinction sites (Ricketts et al 2006) and other Key Biodiversity Areas (Eken et al. 2004) - on the basis of their international importance for the species, biotic communities or habitats they contain, often emphasising their degree of threat and/or irreplaceability (Brooks et al. 2006). However, these arguments, which emphasise the intrinsic value of biodiversity and the associated ethical reasons for its conservation, have not become comprehensively mainstreamed with the wider public or political decision-makers. This is evidenced by the continued decline of biodiversity (Butchart et al. 2010, Tittensor et al 2014) and widespread downgrading, downsizing and degazettement of PAs over the last century (Mascia et al. 2014); a trend which continues to threaten biodiversity.

To address these issues, many conservationists have sought to strengthen the case for conserving sites by demonstrating that they also provide significant benefits (i.e. ecosystem services) to people, and that these benefits can often be attributed a monetary value that resonates at a policy level (Balmford et al. 2002; Fisher et al.2014). Communicating the economic value of goods and services from a site, and their contribution to well-being, helps highlight the growing costs to people of biodiversity loss and ecosystem degradation (TEEB 2010). However, assessing economic benefits of biodiversity and ecosystems alone cannot capture a comprehensive picture of nature's services. In order to account for the true value of the site, it is essential to recognise value pluralism (i.e. multiple distinct values derived from nature that are not reducible to a single [economic] metric) and therefore to measure not only the monetary value but also the site's sociocultural and ecological values (i.e. an integrated ecosystem service valuation; Martín-López et al. 2014; Palomo et al. 2014).

Moreover, benefits from protected areas are generally distributed broadly (i.e. globally) and the costs are often accrued locally, especially in less-developed countries (Balmford \& Whitten, 2003; Adams et al. 2004). Even at the local scale, the influence of the social, political and 
cultural contexts under which resources and benefits accrue to people is important, and reflect the issues of equity and imbalances in power. Many interventions have (sometimes unwittingly) altered the distribution of natural resources benefits, creating winners and losers (especially among those people most directly dependent on natural resources), so undermining their development objectives and becoming the basis of local opposition and rejection (Vira et al 2012). Pre-existing conditions influence whether people are able to access decision-making processes, resources and hence benefits and specific land uses will result in asymmetries in the distribution of environmental benefits and costs between beneficiaries (McDermott et al. 2013). This context has an impact on the subsequent design and implementation of management strategies that build from the ecosystem services assessment.

According to Gómez-Baggethun et al. (2014), an integrated ecosystem service valuation of a site should have the following features. First, the multiple values from the integrated valuation should be able to identify the associated trade-offs and synergies between services and between beneficiaries (Howe et al. 2014). Second, the valuation should be based on multiple knowledge systems (e.g. scientific knowledge, lay knowledge, traditional indigenous knowledge, etc.). Third, both qualitative (e.g. narrative records) and quantitative information should be utilised. Fourth, values emerging at different levels of societal organisation (e.g. individual, communities, nations and global) should be considered. Last, the valuation should accommodate different valuation methods. Together, these features of an integrated valuation can help to elicit a deeper understanding of the ecosystem services provided by a site, and how different decisions affect their distribution (and costs) among stakeholders.

Despite the large number of recent scientific publications referring to the ecosystem services concept, there is a paucity of empirical studies that conduct integrated valuation of ecosystem services provided by individual sites (e.g. Bhagabati et al. 2014). Many studies have focused on broad-scale studies at the global or regional level. Among existing site-scale studies, many are based on intensive, long-term research (e.g., EcoAIM - Ecological Asset Information Management; Exponent 2012) or have used desk-based models (e.g., InVEST - Integrated Valuation of Ecosystem Services and Tradeoffs; Tallis et al. 2013) and methods that require advanced technical knowledge (e.g., ARIES - Assessment and Research Infrastructure for 
Ecosystem Services; Bagstad et al. 2011). However, these approaches require data, capacity and resources that are often limited in those parts of the world where the richest biodiversity is most threatened and where people are most dependent on locally derived ecosystem services.

The general objective of our study was to develop and utilise a practical approach to integrated valuation that could rapidly and relatively cheaply produce locally robust, plural values to help to guide management and policy decisions at a particular site. Specifically, we used the Toolkit for Ecosystem Service Site-based Assessment (TESSA; [Peh et al. 2013a, b]; available at http://tessa.tools/) to quantify the benefits of services provided by a mountain watershed national park in Nepal, in order to investigate if the protection of an area of biodiversity importance also conserves its ecosystem service provision. We compare the hypothetical changes to ecosystem services and their distribution under a highly plausible alternative state of the site (if the protected area had not been established). We then interpret the results in relation to potential management strategies that would protect the site while helping to share the costs and benefits of conservation more fairly among stakeholders.

\section{Methods}

\subsection{Study area}

Shivapuri-Nagarjun National Park (hereafter called the park; Fig. 1) was established in 2002 and covers an area of 15,900 ha consisting of two forest blocks located between $27^{\circ} 45^{\prime}-27^{\circ} 52^{\prime} \mathrm{N}$ and $85^{\circ} 15^{\prime}-85^{\circ} 3^{\prime} \mathrm{E}$ in the central region of Nepal close to Kathmandu. The original Shivapuri forest block $(14,400 \mathrm{ha})$ is demarcated by stone walls; in 2009, the additional Nagarjun forest block (1,500 ha) was gazetted. The park has been identified as an Important Bird and Biodiversity Area for its significant populations of bird species characteristic of the Sino-Himalayan Temperate Forest biome (Baral and Inskipp 2005, BirdLife International 2015) and is the only protected area in the country that falls entirely within the mid-hills mountain range, with its lowest altitude at $1320 \mathrm{~m}$ asl and highest at $2732 \mathrm{~m}$ asl.

Approximately $82 \%$ of the park area is forested, comprising: (1) oak-dominated forests; (2) Schima-Castanopsis-dominated forests; and (3) pine forests (Table 1). The oak (Quercus semecarpifolia)-dominated patches are the mature forests that occur on the steep slopes above 
$2000 \mathrm{~m}$ asl. At lower elevations, Schima-Castanopsis-dominated fragments are the successional forests, recovering from heavy logging that occurred prior to the 1970s. Pine forests consist mainly of chir pine Pinus roxburghii introduced for afforestation purposes. Much of the remaining area is shrubland with small areas of grassland. Approximately $3 \%$ remains as agricultural land due to the continued presence of two human settlements with a total of 350 households. These settlements are permitted to remain inside the park but they are not allowed to harvest wild species within the area.

The park includes major parts of the watershed for the Bishnumati, Mahadev Khola and Bagmati rivers of the Kathmandu Valley, and it therefore influences water delivery patterns into these river systems. There are 28 Village Development Committees (VDCs) with a total of 80,000 inhabitants living in close proximity to the park's boundaries. The immediate area around the park is a mosaic of terraced rice paddy, hillslope agricultural plots, and built-up residential areas with home gardens, which has expanded up the hillslopes in recent years. However, in contrast to many parks in Nepal, recent encroachment into the park by other land-uses such as agriculture is currently non-existent due to (1) the clear demarcation of the park - with a wall - and the fact that it is not possible to receive a land tenure certificate for any land within the boundaries of the park; and (2) frequent patrolling of the park's boundaries by the national army employed as park rangers. In the past ten years a rigid protection regime has been imposed by the park authorities to prohibit extractive activities (e.g. harvesting of fuelwood). Being surrounded by a humandominated landscape, the park provides a useful context in which to study the impact of site protection on ecosystem service provision at a range of spatial scales.

\subsection{Measuring ecosystem services}

The study, carried out in November 2010 - February 2011, used TESSA (Peh et al. 2013a) to assess the net value of some of the ecosystem services delivered by biodiversity and the ecosystems of the park. TESSA aims to guide local management and policy decisions and was chosen over other tools because it has been designed to be used: in situations where there are few existing data; by personnel who have limited technical knowledge, capacity and time (conditions at the Nepal Department of National Parks and Wildlife Conservation [DNPWC]); and at relatively low cost (Peh et al. 2013b). 
Using TESSA, we compared empirical measurements from the park with those from a nearby comparison site, which was carefully chosen to represent the most plausible alternative state of the park. The process comprised: (1) engaging stakeholders to use their local knowledge to determine what the alternative state was likely to be, and therefore; (2) estimating the likely area of each land cover type in the park under the alternative state; and lastly, (3) taking direct relevant measurements, wherever possible, at the park and comparison site to assess the likely change in ecosystem service provision under alternative land use. The delivery of ecosystem services from the park in its current state could then be compared against this plausible alternative. The comparison of the two states (protection versus lack of protection, leading to land use changes) was required in order to assess net costs and benefits (rather than just total values) of conservation, and to reveal who gains and who loses from continued conservation of the site.

The most plausible alternative state of the park was determined through a focus group discussion with the chief warden of the park, three park assistant wardens, four local environmental organisation (Bird Conservation Nepal, BCN) members, three representatives of an international environmental organisation (BirdLife International) and one university researcher. The chief warden, the park assistant wardens and all BCN members had local knowledge of the park from their work experience or long-term field observations. The participants used a topographical map to estimate how the land use would have changed in the event that the park had not been protected. The park's position overlooking Kathmandu means that its land and resources are vulnerable to encroaching agriculture and urbanisation. Near-by sites that best reflected the expected land use changes were then used for measuring the services that would have been delivered under this alternative state.

A preliminary scoping assessment of the range of ecosystem services delivered by the park was also conducted at the same focus group discussion. The purpose of this exercise was to identify the key ecosystem services (according to the CICES classification) and their associated beneficiaries. From this list, we selected four key services for further study, based on their (1) relative importance, (2) likelihood of being affected by the land use change, and (3) their ease of 
measurement using TESSA: global climate regulation, water services (water production and prevention of water sedimentation from soil erosion), nature-based recreation and tourism, and provision of cultivated goods. Methods for measuring the selected ecosystem services were based on guidance in Peh et al. (2013a) and are summarised below (for details see Supporting Information S1). The identification of the beneficiaries was based on the diverse knowledge systems (e.g. local knowledge, formal scientific knowledge, etc.) of the participants, further substantiated by field observations when measuring the associated ecosystem services. We converted all monetary values in this study from Nepalese rupees to US dollars using an average exchange rate for the period between 2010 and 2011 (NR72.50:US\$1.00). It is beyond the scope of TESSA to perform full life cycle analysis of costs and benefits, and we did not consider time horizons and discount rates. Instead, our study was designed to provide an indicative comparison of two different states of the reserve as 'snapshots' in time. Therefore, the assessment does not consider changes in the delivery of services over the long-term.

Global climate regulation - We assessed carbon storage and fluxes of greenhouse gases $\left(\mathrm{CO}_{2}\right.$, $\mathrm{CH}_{4}$ and $\mathrm{N}_{2} \mathrm{O}$ ) for the park under the current (protection) and alternative (no protection) state, based on a combination of field data and appropriate, published, peer-reviewed values (for details see Supporting Information S1). We estimated the potential range in monetary values of carbon stock and overall greenhouse gas fluxes using six estimates of the price of carbon (see Table S1).

Water-related services -As recommended in TESSA, we used the WaterWorld Policy Support System v. 2.4 (hereafter WaterWorld; http://www.policysupport.org/waterworld; Mulligan \& Burke, 2005; Mulligan et al. 2010) to assess the current hydrological baseline for monthly water balance, runoff and soil erosion (as a proxy for water quality). To assess the impacts of land use change, we applied the plausible alternative state (no protection) as a land use 'policy option' within WaterWorld (for details see Supporting Information S1).

Cultivated goods - We estimated the average annual value of agricultural production per hectare by surveying households from two wards within Tokha and Budhanilkantha municipalities near the park (for details see Supporting Information S1 and S2). The mean per hectare value was 
then multiplied by the total number of hectares of cropland in the current state (a small area linked to the two settlements inside the park) and under the alternative state, to estimate how the total value of cultivated goods would have changed if the park had not been established.

Nature-based recreation and tourism - We estimated the value of nature-based tourism from the direct expenditure by local and international visitors to the park. We carried out a field survey at the two main access points to the park using a questionnaire to obtain information on expenditure on travel, food, and guides, and likelihood of people visiting the park under the alternative state (for details see Supporting Information S1 and S3).

Conservation and farming costs - The costs of conservation were estimated from the annual park management budget (provided for 2011 by the park warden), which includes the costs for employing national army personnel in the park (Supporting Information S1). The opportunity cost of farming was represented by the agricultural production survey (for details see Supporting Information S1 and S2). The mean cost per hectare was then multiplied by the total number of hectares of cropland in the current state and under the alternative state.

One-off windfall benefit - We estimated the monetary one-off benefit of harvesting timber and fuelwood during conversion to the alternative state, based on information gathered from our field surveys on above-ground biomass of oak and pine trees, and interviewing local timber yards for the prices of wood products (Table S2; for details see Supporting Information S1).

\subsection{Integrating biophysical and economic dimensions of ecosystem services}

Our rapid ecosystem service assessment, of both the current and alternative states, yielded biophysical (e.g. water quality) and economic (e.g. greenhouse gases sequestration) values. Arguably, we also partly captured the social value through the monetary expenditure of recreation and tourism although inclusion of social values in this study was limited. In order to assess the overall impact of land use conversion on each of these different dimensions of 'value', we standardised the magnitude of each ecosystem service by using rose plots that present the overall balance of services on a common scale of $0-1$, where 1 represents the maximum value 
of the services in either of the two states. Using these rose plots, we examined the synergies and trade-offs among ecosystem services that became apparent across the two states.

\section{Results}

All stakeholders agreed that the most plausible alternative state (lack of protection), if the park had not been established, was the conversion of substantial areas of oak-dominated forest, Schima-Castanopsis forest and pine forest into agricultural and residential areas (Table 1), typical of the surrounding areas. Although the estimated land cover of each habitat type under the alternative state is not spatially explicit, the output (expressed in ha; Table 1) has taken the area's climatic conditions, altitude, slope, and soil type into account. We summarize the net quantity or value of each ecosystem service that would have resulted from such a change in landuse below.

Global climate regulation -We estimated that the above-ground carbon stored in live trees in the oak-dominated forest, mixed Schima-Castanopsis-dominated forest and pine forest averages 284 $\mathrm{Mg} \mathrm{ha}^{-1}, 57 \mathrm{Mg} \mathrm{ha}^{-1}$ and $52 \mathrm{Mg} \mathrm{ha}^{-1}$ respectively; these estimates fall within published ranges for these forest types (Table S3). The total above-ground carbon storage within the park is estimated to be 2.40 million $\mathrm{Mg} \mathrm{C}$, with the old-growth in the oak-dominated forest accounting for $84 \%$ of this carbon storage. We estimate the total carbon (above-ground biomass, below-ground biomass, litter, dead wood and soil) to be 4.50 million Mg C (Table 2; for details see Table S4). The total above-ground live biomass of all habitat types and the total above-ground live biomass in the oak-dominated forest accounted for $49 \%$ and $41 \%$ of the total carbon storage, respectively (Table S4). Stakeholders suggested that lack of protection of the park would have led to an eight-fold increase of croplands and about 3400 ha of residential development. In addition, the area of shrubland would have increased by c. $42 \%$ (Table 1). We estimated that the total above-ground live carbon storage would have decreased by $71 \%$ without protection and the total carbon storage (from the pools of above-ground biomass, below-ground biomass, litter, dead wood and soil) would have declined by $60 \%$ (Table S4; Fig. 2). Based on a monetary value of $\$ 358 \mathrm{Mg}^{-1} \mathrm{C}$ (derived from the latest US Government social carbon value for 2011 , based on a discount rate of $3 \%$ with the incorporation of catastrophic impacts [Interagency Working Group on Social Cost of Carbon, 2013], adjusted for inflation to 2011), this would have led to a loss of 
stored carbon worth $\$ 1,050$ million (Table S1; Fig. 2). The other carbon values used in the sensitivity analysis range from $\$ 23 \mathrm{Mg}^{-1} \mathrm{C}$ (2011 Verified Emission Reductions [VER] market price) to $\$ 415 \mathrm{Mg}^{-1} \mathrm{C}$ (2011 UK Government social carbon price), resulting in a loss of stored carbon estimated at between $\$ 66.5$ million and \$1,210 million, respectively (Table S1). Social carbon costs estimates from 2006 (Stern et al. 2006) are also presented in the sensitivity analysis to illustrate how the monetary value of this ecosystem service might change over time. The difference over time may be due to improved modelling of climate impacts and more recent estimates of damage costs in the literature (Whitton and Tilbury, 2014).

Both states are associated with net sequestration of greenhouse gases, although this would be much reduced if the park had not been protected. We estimated that a total of $96,539 \mathrm{Mg} \mathrm{CO}_{2} \mathrm{eq}$ is sequestered annually by the area in the protected state (Table 2), compared to $25,323 \mathrm{Mg}$ $\mathrm{CO}_{2}$ eq without protection (a 74\% reduction; Fig. 2). This translates into a benefit of protection from avoided carbon loss of $\$ 6.95$ million annually, based on an monetary value of $\$ 98 \mathrm{Mg}^{-}$ ${ }^{1} \mathrm{CO}_{2} \mathrm{eq}$ (derived from the latest US Government social carbon cost for 2011 based on a discount rate of 3\% with the incorporation of catastrophic impacts [Interagency Working Group on Social Cost of Carbon, 2013], adjusted for inflation to 2011; Table S1). Our sensitivity analysis shows a range of carbon prices from $\$ 6 \mathrm{Mg}^{-1} \mathrm{CO}_{2} \mathrm{eq}$ (2011 VER market price) to $\$ 113 \mathrm{Mg}^{-1} \mathrm{CO}_{2} \mathrm{eq}(2011$ UK Government social carbon price), resulting in an avoided carbon loss estimated at between $\$ 0.44$ million and \$8.05 million annually (Table S1) resulting from the protection of the park.

Water provisioning - The main water intakes for Kathmandu are located near the park boundary (Sundarijal, 27.75 N, 85.41 E) and further downstream within the urban area (Mahadev Khola: 27.79 N, 85.37 E and Nagarjun 27.73 N, 85.3 E). We assessed how water flows would have changed in the absence of protection using the WaterWorld Policy Support System to change the coverage of trees, herbs and bare ground from 56\%, 44\% and 0\% (estimated in WaterWorld for the year 2000, since when there has been no significant land cover change) to $20 \%, 59 \%$ and $21 \%$ (based on land cover change in Table 1) respectively. This is associated with increased tree cover in parts of the sparsely forested northern slopes but decreases elsewhere. The reduced tree cover reduces evapo-transpiration by c. $18 \%$ and reduces cloud water interception (sensu: Bruijnzeel et al, 2011) by $15 \%$, leading to an overall increase in water yield of $24 \%$ for the park. 
This would result in greater runoff for the rivers draining into Kathmandu of $0.72 \%, 0.69 \%$, and $1.34 \%$ for the Bishnumati, Mahadev Khola and Bagmati, respectively. However since the park covers only part of the catchments draining into Kathmandu, by the time these rivers reach the city the impact of the land use change is reduced (Fig. 3) to increases in annual flow of 0.1$0.3 \%$. As the park currently discharges 226.7 million L per day, providing a surplus supply of water to Kathmandu (Kunwar 2008), an increment of annual flow (i.e. an additional $2.2-6.8$ million L per day) as the result of land use change would have little impact on water provisioning for the downstream users.

Water quality - Based on WaterWorld, net soil erosion within the park would have increased by an average of $8.5 \mathrm{~mm} / \mathrm{y}$ as a result of this land use change, with consequences for the sustainability of the new agricultural land and for water quality downstream. This would have translated to an $88 \%$ reduction in water quality (Fig. 2). The model output suggests that sediment transport by the rivers entering Kathmandu would have increased under conversion, but with spatial variation. Although the alternative state would have produced a little more water on an annual basis, this water would have arrived with substantial deterioration in quality.

Cultivated goods - Potatoes, rice, wheat, maize, buckwheat, and livestock fodder were the main crops. The average annual value of these mixed-croplands was US\$1,872 ha ${ }^{-1}$. Applying this value to the area under cultivation in both protected and non-protected states (Table 1), the total annual agricultural values were estimated at $\$ 1.44$ million and $\$ 12.2$ million respectively. These values are then offset by farming costs at $\$ 1.18$ million in the protected state and $\$ 9.96$ million in the unprotected state (Table 3).

Nature-based recreation and tourism-The annual number of paying person-visits numbered 167,830 (11,957 international and 155,873 nationals), although this under-estimates total visits because the park grants free access to a large number of school groups and other visitors such as diplomats and researchers. We interviewed 33 international visitors and 60 national visitors. National visitors reported frequently coming to the park to spend time with family and friends and to visit temples and religious sites. On average, international visitors spent \$299 per person on their visit and national visitors spent $\$ 4.60$ per person. The estimated total expenditure 
generated from all visits was $\$ 4.38$ million $\mathrm{y}^{-1}$. When asked if they would have visited the area in the alternative state (i.e. if it hadn't been protected), $33 \%$ of national visitors and $0 \%$ of international visitors said that they would have done. Therefore, the estimated total value of nature-based recreation attributed to the park under the alternative state was $\$ 262,682 \mathrm{y}^{-1}$ (Table 3; Fig. 2).

Conservation costs and one off windfall benefit - The annual park management budget for 2010/11 was $\$ 200,000$. The budget for employing army personnel in 2010/2011 was \$2.89 million $\mathrm{y}^{-1}$. Therefore the total annual conservation cost was estimated at $\$ 3.09$ million. During conversion of the park to the alternative state land-use, a one off benefit from the wood products would have been gained in the form of timber (oak and pine) and fuelwood (mainly deadwood). Using standardised conversion factors from IPCC (2006) and local market values for these products, the net benefit (minus harvesting and processing costs) is estimated at \$18.6 million from timber and \$14,238 from fuelwood (Table S3). Hence, the decision to conserve the park's forest imposed on the Nepalese government an opportunity cost of \$18.6 million over the course of one cutting cycle.

Overall summary of results - The net annual benefit of the service flow and the net stock benefit provided by the protected area are estimated to be $\$ 11$ million (or $\$ 690 \mathrm{ha}^{-1}$ ) and $\$ 1,740$ million (or $\$ 110,000 \mathrm{ha}^{-1}$ ), respectively, using the recent US Government social price for $\mathrm{CO}_{2}$ of $\$ 98$ $\mathrm{Mg}^{-1} \mathrm{CO}_{2}$ (Table 3). The overall difference in net annual value of services from the area in the presence and absence of protection is estimated at $\$ 6.04$ million ( $\$ 380 \mathrm{ha}^{-1} \mathrm{y}^{-1}$; Table 3). The estimated difference in net value of carbon stock between these states is $\$ 1,030$ million (Table 3). These economic gains are mainly global societal benefits, mediated through global climate regulation services.

However, our estimates of the net annual benefit of the service flow and the net stock benefit were based only on those services valued in monetary terms. Some services that were measured were reported in non-economic dimensions of 'value' (e.g. biophysical value of water quality) and were left out of our simplified cost-benefit analysis (Table 3). However, these non-economic dimensions of the ecosystem service are represented together with other economic benefits in 
rose plots (Fig. 2) These rose plots - comparing ecosystem service (of different dimensions of 'value') delivery between two states - do not merely put together different ecosystem service values, but present a powerful means to illustrate how different values stand in relation to each other. They reveal trade-offs and synergies among the services when comparing the two states. Fig. 2 reveals that positive synergies are achieved when actions to protect the park for biodiversity conservation benefit other services or local beneficiaries. For example, the protection of forest cover can reduce soil erosion and protect water quality, which ultimately enhances recreation opportunities. Conversely, Fig. 2 also highlights that potential trade-offs can occur when actions to increase food production within the park reduce other services. For example, the conversion of forest into farmland may decrease carbon dioxide sequestration, degrade water quality and reduce the attractiveness of the area for recreation.

Although overall we are confident that the results presented are a meaningful comparison between the two alternative states, there are varying levels of uncertainty related to the accuracy and precision of the data for each ecosystem service. We used a simple qualitative scale of 'high', 'medium' and 'low' to assess the degree of confidence in the results (Table 4). We performed a quantitative analysis of our carbon value, using a range of carbon prices (Table S1), to assess how sensitive the overall result was to a chosen carbon price. We showed that the magnitude of the net monetary benefit of conservation in this study is highly sensitive to carbon prices (e.g. the percentage of the net monetary benefit that corresponds to the lowest [2011 VER market price] and highest carbon prices [2011 UK Government social carbon cost] are 18\% and $88 \%$, respectively). Importantly, our results showed that even when the lowest carbon price is chosen, there is a net carbon stock benefit from protection of almost $\$ 47.9$ million. Therefore a critical component of valuing carbon stock is the choice of carbon prices, which depends on the purpose of the analysis. For example a carbon price based on the market value should be used for a financial project appraisal, whereas in the context of UK policy decisions (e.g. relating to overseas development aid), the social carbon price provided by the UK Department of Energy and Climate Change would be most appropriate.

Our analyses showed that there are significant ecosystem service benefits (from carbon, water, and nature-based tourism) from the protection of the park. However, the beneficiaries of these 
services are mainly district (Kathmandu water users), national (National Parks department), and global (climate regulation, biodiversity) in scale, and not the local communities living around the park (Table 4). Conversely, under the 'no protection' alternative state, the global community would have lost out as a result of reduced climate regulation, whereas local communities would have gained by being able to expand their farming activities and to collect fuelwood during the land use conversion. The negative impacts of land-use change on water quality under the alternative state could also have affected the health of downstream users (including 1.7 million urban inhabitants in Kathmandu) and the profits of the private water company (which might have had to invest in improved filtration facilities). In addition, local and nearby communities would have lost access to the income associated with recreational visits, although due to the presence of temples, the alternative state would still have provided considerable recreational and cultural services.

\section{Discussion}

We provide evidence that the protection of a Himalayan protected area of biodiversity conservation importance has a net economic and social advantage for people. Our rapid assessment utilised a framework and associated tools which illustrate a practical approach to integrated valuation to inform decision-making. First, the multiple types of values (expressed in both biophysical and monetary metrics) arose from different assessment methods - including surveys of recreational visitors, quantitative ecological measurements of carbon stored in trees and the use of ecological models to quantify water flow. This enabled us to examine trade-offs and synergies between different ecosystem services; only an integrated approach could elicit such a clear trade-off between provision of cultivated goods and water quality in this context. Second, the application of the practical toolkit relies heavily on different knowledge systems; the scientific knowledge held by the researchers, lay knowledge from the conservation practitioners and local knowledge from the park wardens are all critical sources of information for enhancing our understanding of the services provided by the dynamic social-ecological systems. Last, the use of the toolkit enables collection of information at different levels of societal organisation from individuals (e.g. recreational visitors) to local communities (e.g. farmers) -for understanding the distribution of beneficiaries within and beyond the protected areas. 
A key insight that derives from this study is that focus on economic analysis could define the outcome of an ecosystem service assessment. Specifically our results show that economic dimension of 'value' was dominant especially when the price of carbon was the most important ingredient. However, the net monetary gain from protecting the park (largely accounted for by social carbon costs) was mainly a benefit for global communities, rather than directly and economically-beneficial to local communities. Hence the monetary benefit of ecosystem services was not received by the local people who beared the costs of maintaining these ecosystem services. This finding is consistent with the current discussion about the role of integrated valuation where there is a need to give more importance to the non-monetary (e.g. social, ecological, etc.) dimensions of value (Chan et al. 2012; Martín-López et al. 2014). Our work has showcased the use of rose plots in integrating biophysical and monetary values.

While this study shows the usefulness of TESSA as an integrated ecosystem service valuation tool, it also highlights the current limitation of this approach. The social dimension of ecosystem services (sensu preference assessment) was not included in this study, so there was a bias towards biophysical and monetary dimensions of value (Chan et al., 2012). The exclusion of cultural ecosystem services in this study - spiritual and religious values, aesthetic values, sense of place, cultural heritage - that rely on qualitative information underscores the need for further developing TESSA methods to adapt them for a more fully integrated valuation (work that is ongoing).

We could also have improved the approach in this case by involving a wider range of stakeholders (including local people) in the process to identify and value the benefits and costs. Furthermore, given the rapid approach, we were not able to assess all services listed at the scoping exercise, such as air quality regulation and nutrient cycling. Potential provision of harvested wild goods (e.g. fuelwood, fodder, wild fruits and vegetable, timber and fish) was also recognised, if the harvesting of these goods were not prohibited by law. We speculate that all these services would have declined under the alternative state. Therefore, our estimate of net ecosystem service value lost due to the land use conversion is probably conservative. 
In this study, we present two different types of monetary values: those for goods that are actually traded on markets (e.g. harvested wood products; Table 3) and those that remain virtual unless an adequate mechanism or governance option is implemented for trading them (e.g. PES or REDD+ scheme for carbon storage; Fig. 2C). The latter category arguably captures a more comprehensive picture of the economic value of the protected area. Monetary benefits of services that are delivered and consumed in the absence of market transactions, however, can materialise only if there are cost-effective incentives to stimulate the conservation of such services (Adams 2014).

We have considered the distribution of economic benefits and costs of the park and how the change in land-use would have impacted people at different spatial scales. Our analyses show that the conservation benefits of this mountain protected area in Nepal are mainly accrued to downstream water users and the global community, the latter through tourism and global climate regulation. Resolving such distributional issues will require a process of consultation and compromise and this would be a necessary step in any follow up to this assessment at the park. Such a decision-making process is a significant challenge because stakeholders typically promote their own values and interests and exercise their varying degrees of power to influence the outcome. Powerful actors with entrenched interests often oppose changes to the status quo, making it hard to bring about changes that have potential to deliver more socially desirable outcomes (Vira et al 2012). This can be seen within the context of Nepal's community forestry programme where equity challenges occur between the state and communities (e.g. recognition of rights, management autonomy, revenue sharing and service provision), between communities (e.g. impacts of herders in high mountains on users of water in the lowlands), and within communities (e.g. elite capture in representation, decision-making and benefit sharing) (Birch et al. 2014; Paudel 2015).

The equity issues elicited in this study should be further explored to inform a sustainable management strategy for the long-term conservation of the park's biodiversity and ecosystem services. Improved benefit-sharing mechanisms could address the imbalance of benefits currently provided by the site. One option would be to establish a buffer zone that cover $126 \mathrm{~km}^{2}$ encompassing 154 wards of 28 VDCs around the park, as is currently being proposed in the 
revised management plan for the park (DNPWC, 2014). In Nepal, communities living within park Buffer Zones receive 30-50\% of park revenue (from entry fees and any fines/penalties) for conservation and development projects. Decisions on how to use the funds are made by community-based Buffer Zone Management Committees. If a buffer zone were created in the future, the park's revenue (currently from entry fees, but potentially in the future also from REDD+ payments) would enable local communities to benefit directly from conservation, though these payments are only significant if the park receives substantial income. By redressing the imbalance in the costs and benefits of conservation, and restoring some rights to local people, those who then share in the benefits from the park (the majority) are expected to apply pressure for more pro-social behaviour by those acting in ways which damage the park and put the community benefits at risk.

Another option could be the development of a fiscal instrument such as a Payment for Ecosystem Services (PES) or similar incentive scheme, specifically for watershed services. PES is still in its infancy in Nepal, but there are some private schemes in place (e.g. the Khulekhani watershed [Khatri 2009]) and a government PES policy is being formulated (coordinated by The Ministry of Forests and Soil Conservation and the Ministry of Local Development, also involving other concerned ministries and the National Planning Commission). A critical part of this is the development of a legal framework to establish who can legally benefit from water services and by how much, ensuring that upstream local communities receive fair payment for the waterrelated ecosystem service benefits that their land-use management helps to deliver (Greiber 2009). Given that the park is an important part of the catchment for regulated, clean water supplies to the city, it would be worth exploring the feasibility of establishing a payment system between the beneficiaries of watershed protection (Kathmandu residents and the water company) and the local people who incur opportunity costs through forest protection. However, issues of equity and power imbalances again need to be considered. Although PES schemes aim to find synergies which maximise benefits to environmental stakeholders - they are not immune to the problem of trade-offs (Redford and Adams 2009). Indeed, PES schemes, by commodifying environmental services, create new relationships with land and natural resources, and new issues of ownership, responsibility and property rights (Reid and Nsoh 2014). This has also raised concerns over equity, particularly at the local level, as with the transformation in values that 
accompanies the entry of ecosystem services into a market system, politics and power may disenfranchise local communities, worsening local inequalities (REDD-Net 2011; Franks and Quesada-Aguilar 2014). Any exploration of the suitability of a PES scheme at the park needs to be mindful of the equity implications.

\section{Conclusion}

Although sites are generally prioritised for conservation based on their biodiversity values (and threats to and irreplaceability of these), they can also provide many services which benefit human well-being in a variety of ways and at different spatial scales. Our study shows how integrated valuation of ecosystem services in a conservation context can shed light on a site's additional value to society and indicate suitable strategies for enhancing economic sustainability and human well-being, while maintaining biodiversity values. We hope that our results will contribute to helping policy-makers recognise the values of protected areas, understand better the trade-offs involved, and address how benefits can be more equitably shared by the people who are engaged in or impacted by the conservation and management of these areas. Our results support the Government of Nepal's current strategy of transferring more benefits to the local level, with promising interventions including the development of mechanisms for access and benefit sharing (through buffer zone creation) and PES schemes to compensate local communities for the local-level cost of restricting access to forest resources.

\section{Acknowledgements}

We are grateful to the Cambridge Conservation Initiative (research grant no. PFPA.GAAB), the AXA Research Fund, France (to KSHP at Cambridge University; RG64520) and the UK Government's Darwin Initiative (18-005) for funding this project. We also thank staff at the park and Bird Conservation Nepal for their assistance and the respondents to all the questionnaire surveys conducted as part of the assessment.

\section{References}

Adams, W.M., Aveling, R., Brockington, D., Dickson, B., Elliott, J., Hutton, J., Roe, D., Bhaskar, V., Wolmer, W., 2004. Biodiversity conservation and the eradication of poverty. Science 306, 1146-1149. 
Bagstad, K.J., Villa, F., Johnson, G.W., Voigt, B., 2011. ARIES - Artificial Intelligence for Ecosystem Services: A guide to models and data, version 1.0. ARIES report series n.1. http://www.ariesonline.org/docs/ARIESModelingGuide1.0.pdf. Accessed on 28 June 2014 Balmford, A., Bruner, A., Cooper, P., Costanza, R., Farber, S. Green, R.E., Jenkins, M., Jefferiss, P., Jessamy, V., Madden, J., Munro, K., Myers, N., Naeem, S., Paavola, J., Rayment, M., Rosendo, S., Roughgarden, J., Trumper, K., Turner, R.K., 2002. Economic reasons for conserving wild nature. Science 297, 950-953.

Balmford, A., Whitten, T., 2003. Who should pay for tropical conservation, and how could the costs be met? Oryx 37, 238-250.

Baral, H. S., Inskipp, C., 2005. Important Bird Areas in Nepal: key sites for conservation, Bird Conservation Nepal and BirdLife International, Kathmandu and Cambridge.

Bhagabati, N.K., Ricketts, T., Sulistyawan T.B.S., Conte, M., Ennaanay, D., Hadian, O., McKenzie, E., Olwero, N., Rosenthal, A., Tallis, H., Wolny, S. 2014. Ecosystem services reinforce Sumatran tiger conservation in land use plans. Biol. Consery. 169, 147-156.

BirdLife International, 2014. Important Bird and Biodiversity Areas: a global network for conserving nature and benefiting people, BirdLife International, Cambridge.

BirdLife International, 2015. Important Bird and Biodiversity Area factsheet: ShivapuriNagarjun National Park. http://www.birdlife.org. Accessed on 13 November 2015

Birch, J.C., Thapa, I., Balmford, A., Bradbury, R.B., Brown, C., Butchart, S.H.M., Gurung, H., Hughes, F.M.R., Mulligan, M., Pandeya, B., Peh, K.S.-H., Stattersfield, A.J., Walpole, M., Thomas, D.H.L., 2014. What benefits do community forests provide, and to whom? A rapid assessment of ecosystem services from a Himalayan forest, Nepal. Ecosyst. Services 8, 118-127.

Brooks, T.M., Mittermeier, R.A., da Fonseca. G.A.B., Gerlach, J., Hoffmann, M., Lamoreux, J.F., Mittermeier, C.G., Pilgrim, J.D., Rodrigues, A.S.L., 2006. Global biodiversity conservation priorities. Science 313, 58-61.

Bruijnzeel, L.A., Mulligan, M., Scatena, F.N. 2011.Hydrometeorology of tropical montane cloud forests: Emerging patterns. Hydrol. Process. 25, 465-498.

Butchart, S.H.M., Walpole, M., Collen, B., van Strien, A., Scharlemann, J.P.W., Alond, R.E.A., Baillie, J.E.M., Bomhard, B., Brown, C., Bruno, J., Carpenter, K.E., Carr, G.M., Chanson, J., Chenery, A.M., Csirke, J., Davidson, N.C., Dentener, F., Foster, M., Galli, A., Galloway, J.N., Genovesi, P., Gregory R.D., Hockings, M., Kapos, V., Lamarque, J.-F., Leverington, F., Loh, J., McGeoch, M.A., McRae, L., Minasyan, A., Morcillo, M.H., Oldfield, T.E.E., Pauly, D., Quader, S., Revenga, C., Sauer, J.R., Skolnik, B., Spear, D., Stanwell-Smith, D., Stuart S.N., Symes, A., Tierney, M., Tyrrell, T.D., Vié, J.-C., Watson, R., 2010. Global biodiversity: indicators of recent declines. Science 328, 1164-1168. 
Chan, K.M.A., Satterfield, T., Goldstein. J., 2012. Rethinking ecosystem services to better address and navigate cultural values. Ecol. Econ. 74, 8-18.

DNPWC, 2014. Shivapuri Nagarjun National Park and proposed buffer zone: management plan. Draft version. Ministry of Forests and Soil Conservation, Nepal.

Eken, G., Bennun, L., Brooks, T.M., Darwall, W., Fishpool, L.D.C., Foster, M., Knox, D., Langhammer, P., Matiku, P., Radford, E., Salaman, P., Sechrest, W., Smith, M.L., Spector, S., Tordoff, A. 2004.Key biodiversity areas as site conservation targets. BioScience 54, 1110-1118.

Exponent, 2012. Environmental Perspectives. Volume 1. http://www.exponent.com/files/Uploads/Documents/Newsletters/EP_Volume1_2012.pdf. Accessed on 28 June 2014

Fisher, J.A., Patenaude, G., Giri, K., Lewis, K., Meir, P., Pinho, P., Rounsevell, M.D.A., Williams, M. 2014. Understanding the relationships between ecosystem services and poverty alleviation: a conceptual framework. Ecosyst. Serv. 7, 34-45.

Franks, P., Quesada-Aguilar, A., 2014. Equitable REDD+: Exploring concepts and strategies. IIED Discussion Paper. IIED, London.

Gómez-Baggethun, E., Martín-López, B.,Barton, D., Braat, L., Saarikoski, H., Kelemen, GarcíaLlorente, M., van denBergh, E.J., Arias, P., Berry, P., Potschin, L.M., Keene, H., Dunford, R., Schröter-Schlaak, C., Harrison, P., 2014. State-of-the-art report on integrated valuation of ecosystem services. EU FP7 OpenNESS Project Deliverable 4.1., European Commission FP7.

Greiber, T., 2009. Payments for Ecosystem Services. Legal and Institutional Frameworks. IUCN, Gland, Switzerland. 296 pp.

Howe, C., Suich, H., Vira, B. and Mace, G.M., 2014. Creating win-wins from trade-offs? Ecosystem services for human well-being: A meta-analysis of ecosystem services trade-offs and syneries in the real world. Global Environ. Chang. 28, 263-275.

Interagency Working Group on Social Cost of Carbon, 2013. Technical Update of the Social Cost of Carbon for Regulatory Impact Analysis Under Executive Order 12866. Revised July 2015. Interagency Working Group on Social Cost of Carbon, United States Government.

IPCC, 2006. 2006 IPCC Guidelines for National Greenhouse Gas Inventories, Prepared by the National Greenhouse Gas Inventories Programme, Eggleston H. S., L. Buendia, K. Miwa T. Ngara and K. Tanabe (eds). Published: IGES, Japan.

IUCN 2011. IUCN Red List of Threatened Species. Version 2011.2. http://www.iucnredlist.org. Accessed 16 November 2011. 
Juffe-Bignoli, D., Burgress, N.D., Bingham, H., Belle, E.M.S., de Lima, M.G., Deguignet, M., Bertzky, B., Milam, A.N., Martinez-Lopez, J., Lewis, E., Eassom, A., Wicander, S., Geldmann, J., van Soesbergen, A., Arnell, A.P., O’Connor, B., Park, S., Shi, Y.N., Danks, F.S., MacSharry, B., Kingston, N., 2014. Protected Planet Report 2014. UNEP-WCMC, Cambridge.

Khatri, D.B., 2009. Environmental Services and Institutions: A case from Khulekhani Watershed, Lambert Academic Publishing, Nepal.

Kunwar, K.J., 2008. Payment for environmental services in Nepal (A case study of Shivapuri National Park, Kathmandu, Nepal). The Initation 2, 63-72.

Martín-López, B., Gómez-Baggethun, E., García-Llorente, M., \& Montes, C., 2014. Trade-offs across value-domains in ecosystem services assessment. Ecol. Indic. 37, 220-228.

Mascia, M.B., Pailler, S., Krithivasan, R., Roshchanka, V., Burns, D., Mlotha, M.J., Murray, D.R., Peng, N., 2014. Protected area downgrading, downsizing, and degazettement (PADDD) in Africa, Asia, and Latin America and the Caribbean, 1900-2010. Biol. Conserv. 169, 355-361.

McDermott, M., Mahanty, S., Schreckenberg, K., 2013. Examining equity: a multidimensional framework for assessing equity in payments for ecosystem services. Environ. Sci. Policy 33, 416-427.

Mulligan, M., Burke, S.M., 2005. FIESTA: Fog Interception for the Enhancement of Streamflow in Tropical Areas. Report to UK DFID, 174

Mulligan, M., Rubiano, J., Hyman, G., White, D., Garcia, J., Saravia, M., Leon, J.G., Selvaraj, J.J., Gutierrez, T., Saenz-Cruz, L.L., 2010. The Andes 'basin': biophysical and developmental diversity in a climate of change. Water Int. 35, 472-492.

Palomo, I., Montes, C., Martín-López, B., González, J.A., García-Llorente, M., Alcorlo, P., Mora, M.R.G., 2014. Incorporating the social-ecological approach in protected area in the anthropocene. BioScience, doi:10.1093/biosci/bit033.

Paudel, N.S., 2015. Nepal's community forestry (CF) and lessons on equity. Expert workshop on Equity, Justice and Well-being in Ecosystem Governance, 26-27 March 2015, London. http://www.slideshare.net/IIEDslides/community-forestry-and-equity-in-nepal Accessed on 30 October 2015.

Pearson, T., Walker, S.,Brown, S., 2005. Sourcebook for land use, land-use change andforestry projects. Winrock International. http://www.planvivo.org/wp-

content/uploads/LULUCF_Sourcebook_compressed11.pdf. Accessed on 28 June 2014

Peh, K.S.-H., Balmford, A.P., Bradbury, R.B., Butchart, S.H.M., Brown, C., Hughes, F.M.R., Stattersfield, A.J., Thomas, D., Walpole, M., Birch, J.C., 2013a. Toolkit for Ecosystem 
Service Site-based Assessment, Cambridge Conservation Initiative, Cambridge.

Peh, K.S.-H., Balmford, A.P., Bradbury, R.B., Butchart, S.H.M., Brown, C., Hughes, F.M.R., Stattersfield, A.J., Thomas, D., Walpole, M., Birch, J.C., 2013b. Measuring and monitoring ecosystem services at the site scale: a practical toolkit. Ecosyst. Serv. 5, 51-57.

REDD-NET, 2011. A framework for defining equity. Policy Brief, October 2011.

Redford, K.H., Adams, W.M., 2009. Payment for Ecosystem Services and the Challenge of Saving Nature. Conserv. Biol. 23, 785-87.

Reid, C.T., Nsoh, W., 2014. Whose ecosystem is it anyway? Private and public rights under new approaches to biodiversity conservation. Journal of Human Rights and the Environment 5, 112135.

Ricketts, T.H., Dinerstein, E., Boucher, T., Brooks, T.M., Butchart, S.H.M., Hoffmann, M. Lamoreux, J.F., Morrison, J., Parr, M., Pilgrim, J.D., Rodrigues, A.S.L., Sechrest, W., Wallace, G.E., Berlin, K. Bielby, J., Burgess, N.D., Church, D.R., Cox, N., Knox, D., Loucks, C., Luck, G.W., Master, L.L., Moore, R., Naidoo, R., Ridgely, R., Schatz, G.E., Shire, G., Strand, H., Wettengel, W., Wikramanayake, W., 2005. Pinpointing and preventing imminent extinctions. PNAS 102, 18497-18501.

Stern, N.H., Peters, S., Bakhshi, V., Bowen, A., Cameron, C., Catovsky, S., Crane, D., Cruickshank, S., Dietz, S., Edmonson, N., Garbett, S.-L., Hamid, L., Hoffman, G., Ingram, D., Jones, B., Patmore, N., Radcliffe, H., Sathiyarajah, R., Stock, M., Taylor, C., Vernon, T., Wanjie, H., Zenghelis, D., 2006. Stern review: the economics of climate change, Cambridge University Press, Cambridge, UK http://webarchive.nationalarchives.gov.uk/+http:/www.hmtreasury.gov.uk/sternreview_index.htm. Accessed on 28 June 2014

Tallis, H.T., Ricketts, T., Guerry, A.D., Wood, S.A., Sharp, R., Nelson, E., Ennaanay, D., Wolny, S., Olwero, N., Vigerstol, K., Pennington, D., Mendoza, G., Aukema, J., Foster, J., Forrest, J., Cameron, D., Arkema, K., Lonsdorf, E., Kennedy, C., Verutes, G., Kim, C.K., Guannel, G., Papenfus, M., Toft, J., Marsik, M., Bernhardt, J., Griffin, R., 2013. InVEST 2.5.3 User's Guide. The Natural Capital Project, Stanford. http://www.naturalcapitalproject.org/InVEST.html Accessed on 13 November 2015.

TEEB. 2010. The Economics of Ecosystems and Biodiversity: Mainstreaming the Economics of Nature: A Synthesis of the Approach, Conclusions and Recommendations of TEEB.

Tittensor, D.P., Walpole, M., Hill, S.L.L., Boyce, D.G., Britten, G.L., Burgess, N.D., Butchart, S.H.M., Leadley, P.W., Regan, E.C., Alkamade, R., Baumung, R., Bellard, C., Bouwman, L., Bowles-Newark, N.J., Chenery, A.M., Cheung, W.W.L., Christensen, V., Cooper, H.D., Crowther, A.R., Dixon, M.J.R., Galli, A., Gaveau, V., Gregory, R.D., Gutierrez, N.L., Hirsch, T., Hoft, R., Januchowski-Hartley, S.R., Karmann, M., Krug, C.B., Leverington, F.J., Loh, J., 
Lojenga, R.K., Malsch, K., Marques, A., Morgan, D.H.W., Newbold, T., Noonan-Mooney, K., Pagad, S.N., Parks, B.C., Pereira, H.M., Robertson, T., Rondinini, C., Santini, L., Schindler, S., Sumaila, U.R., The, L.S.L., van Kolck, J., Visconti, V., Ye, Y., 2014 A mid-term analysis of progress towards international biodiversity targets. Science 346, 241-244.

Vira, B., Adams, W.M, Agarwal, C., Badiger, S., Hope, R.A, Krishnaswamy, J., Kumar, C., 2012. Negotiating Trade-offs: choices about ecosystem services for poverty alleviation. Economic and Political Weekly 47, 67-75.

Whitton, Z., Tilbury, J., 2014. The social cost of carbon: a review for corporate decision makers. Veratas. 
Table 1. Land cover change. Estimated land cover under the current state (with protection) and alternative state (no protection) of Shivapuri-Nagarjun National Park.

\begin{tabular}{lrr}
\hline Habitat type & Protection (ha) & No protection (ha) \\
\hline Oak-dominated broadleaf forest & 7,111 & 1,956 \\
Schima-Castanopsis forest & 5,248 & 1,011 \\
Pine forest & 754 & 218 \\
Shrubland & 1,934 & 2,745 \\
Cropland & 771 & 78,493 \\
Grassland & 78 & 4 \\
Bareground & 4 & 3,394 \\
Urban & - & $\mathbf{1 5 , 9 0 0}$ \\
\hline Total & $\mathbf{1 5 , 9 0 0}$ & 48 \\
\hline
\end{tabular}


Table 2. Carbon stored and greenhouse gas (GHG) fluxes by habitat types at the Shivapuri-Nagarjun National Park under current (with protection) and alternative (no protection) states.

\begin{tabular}{|c|c|c|c|c|c|}
\hline \multirow[t]{2}{*}{ State } & \multirow[t]{2}{*}{ Habitat type } & \multicolumn{2}{|l|}{$\begin{array}{c}\text { Carbon storage } \\
(\mathrm{Mg})\end{array}$} & \multicolumn{2}{|c|}{ GHG sequestration ( $\left.\mathrm{Mg} \mathrm{CO} 2 \mathrm{eq}^{-1}\right)$} \\
\hline & & Total & Potential range & & Total \\
\hline \multirow[t]{9}{*}{ Protection } & $\begin{array}{l}\text { Oak-dominated broadleaf } \\
\text { forest }\end{array}$ & $3,771,384$ & & & 46,693 \\
\hline & Schima-Castanopsis forest & 703,712 & & & 34,461 \\
\hline & Pine forest & 93,686 & & & 4,952 \\
\hline & Shrubland & 262,991 & & & 11,805 \\
\hline & Cropland & 29,575 & & - & 1,479 \\
\hline & Grassland & 2,643 & & & 107 \\
\hline & Bareground & 131 & & & - \\
\hline & Urban & - & & & - \\
\hline & Total & $4,864,122$ & $3,512,878-6,215,367$ & & 96,539 \\
\hline \multirow[t]{9}{*}{$\begin{array}{l}\text { No } \\
\text { protection }\end{array}$} & $\begin{array}{l}\text { Oak-dominated broadleaf } \\
\text { forest }\end{array}$ & $1,037,512$ & & & 12,845 \\
\hline & Schima-Castanopsis forest & 135,530 & & & 6,637 \\
\hline & Pine forest & 27,134 & & & 1,434 \\
\hline & Shrubland & 373,346 & & & 16,758 \\
\hline & Cropland & 249,152 & & - & 12,459 \\
\hline & Grassland & 2,643 & & & 107 \\
\hline & Bareground & 131 & & & - \\
\hline & Urban & 115,405 & & & - \\
\hline & Total & $1,940,853$ & $1,174,262-2,707,443$ & & 25,323 \\
\hline
\end{tabular}


Table 3. Net values of ecosystem services (those for which monetary values were available; 2011 values) resulting from protection of ShivapuriNagarjun National Park. Values of greenhouse gas regulation are based on a more conservative social carbon cost (see Table S1).

\begin{tabular}{|c|c|c|c|c|}
\hline & $\begin{array}{r}\text { Protection (\$) } \\
(15,900 \mathrm{ha})\end{array}$ & $\begin{array}{r}\text { No protection (\$) } \\
(15,900 \mathrm{ha})\end{array}$ & $\begin{array}{r}\text { Difference }(\$) \\
(15,900 \text { ha })\end{array}$ & $\begin{array}{l}\text { Difference } \\
\left(\$ \text { ha }^{-1} \mathrm{y}^{-1}\right)\end{array}$ \\
\hline \multicolumn{5}{|l|}{ Service flow $\left(\$ y^{-1}\right)$} \\
\hline Greenhouse gases sequestration & $9,427,050$ & $2,472,765$ & $6,954,285$ & 437 \\
\hline Cultivated goods & $1,442,926$ & $12,155,720$ & $10,712,794$ & 674 \\
\hline Nature-based tourism & $4,378,815$ & 262,682 & $4,116,133$ & 259 \\
\hline Conservation costs & $3,093,981$ & 0 & $3,093,981$ & 195 \\
\hline Farming costs & $1,182,231$ & $9,959,540$ & $8,777,309$ & 552 \\
\hline Net annual benefit & $10,972,579$ & $4,931,627$ & $6,040,952$ & 380 \\
\hline Net annual benefit per hectare & 690 & 310 & 380 & \\
\hline \multicolumn{5}{|l|}{ Service stock (\$) } \\
\hline Carbon storage & $1,743,182,213$ & $695,553,991$ & $1,047,628,222$ & 65,889 \\
\hline One-off benefit from harvest wood products during conversion & 0 & $18,629,761$ & $18,629,761$ & 1,172 \\
\hline Net stock benefit & $1,743,182,213$ & $714,183,752$ & $1,028,998,461$ & 64,717 \\
\hline Net stock benefit per hectare & 109,634 & 44,917 & 64,717 & \\
\hline
\end{tabular}


Table 4. Magnitude of change in delivery of different ecosystem services if the site had not been protected, shown for beneficiaries at the local, national and global scale. “ $\uparrow$ indicates increase, “ $\downarrow ”$ indicates decrease, “=” indicates no change, and number of symbols indicates relative magnitude of change. Level of confidence estimates provided for each service valuation are based on the classification scheme provided in TESSA (Peh et al.2013a).

\begin{tabular}{|c|c|c|c|c|c|c|}
\hline \multirow[b]{2}{*}{ Ecosystem service } & \multirow[b]{2}{*}{ Local } & \multicolumn{3}{|c|}{ Location of beneficiaries } & \multirow{2}{*}{$\begin{array}{c}\text { Level of confidence over } \\
\text { estimates }\end{array}$} & \multirow[t]{2}{*}{ Comments on level of confidence } \\
\hline & & District & National & Global & & \\
\hline \multicolumn{7}{|l|}{ Change in annual flows if not protected } \\
\hline Greenhouse gas sequestration & $=$ & $=$ & $=$ & $\downarrow \downarrow$ & Low & $\begin{array}{l}\text { Estimates were based on look-up values - } \\
\text { from scientific literature - derived from } \\
\text { small sample sizes. }\end{array}$ \\
\hline Water provision & $\uparrow$ & $\uparrow$ & $=$ & $=$ & Low & $\begin{array}{l}\text { Estimates were derived by treating } \\
\text { vegetation biophysically rather than as } \\
\text { particular crop/management complexes and } \\
\text { were based on global datasets, limiting their } \\
\text { accuracy at local scale. This could be } \\
\text { improved through incorporating better local } \\
\text { data where available. }\end{array}$ \\
\hline Water quality & $=$ & $\downarrow \downarrow \downarrow$ & $=$ & $=$ & Low & $\begin{array}{l}\text { As above; estimates could be improved by } \\
\text { incorporating local level maps }\end{array}$ \\
\hline Cultivated goods & 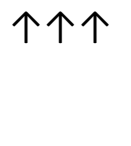 & $=$ & $=$ & $=$ & Medium & $\begin{array}{l}\text { Estimates were derived using field } \\
\text { measurements but from relatively small } \\
\text { sample sizes. }\end{array}$ \\
\hline Nature-based recreation & $=$ & $\downarrow \downarrow \downarrow$ & $\downarrow \downarrow \downarrow$ & $\downarrow \downarrow \downarrow$ & Medium & $\begin{array}{l}\text { Estimates were based on existing published } \\
\text { data combined with field surveys but from } \\
\text { relatively small sample sizes. }\end{array}$ \\
\hline Change in stock if not protected & & & & & & \\
\hline
\end{tabular}


Carbon storage

Wood products
$=$

$=$

$=$

$=$ $\downarrow \downarrow$

西
Medium

Medium
Estimates were derived from field measurements but using relatively small sample sizes and generic allometric equations at the level of genus or forest type. Site boundary definition, area stratification, and classification of forest types were robust.

Estimates were based on field surveys, and visits to local timber yards, combined with conversion factors from IPCC (2006). 
Figure legends

Figure 1. Location of Shivapuri-Nagarjun National Park in Nepal. The National Park consists of two sections: Shivapuri and Nagarjun.

Figure 2. Rose plots to show differences in ecosystem service values between the current (A, protection) and the alternative state (B, no protection) for annual flows of greenhouse gas sequestration, water provision, water quality, cultivated goods and nature-based tourism (for which 1 equates to the maximum value in either state for each service); and bar chart of one-off stock changes $(\mathrm{C})$ that would have occurred during conversion to the alternative state.

Figure 3. Screen capture from WaterWorld showing areas of increased annual runoff (green to red) for the alternative state (no protection) of the site expressed as a percentage of current runoff (based on a baseline in the year 2000). Map data: Google, AutoNavi.

http://support.google.com/maps/bin/static.py?hl=en\&ts=1342531\&page=ts.cs 


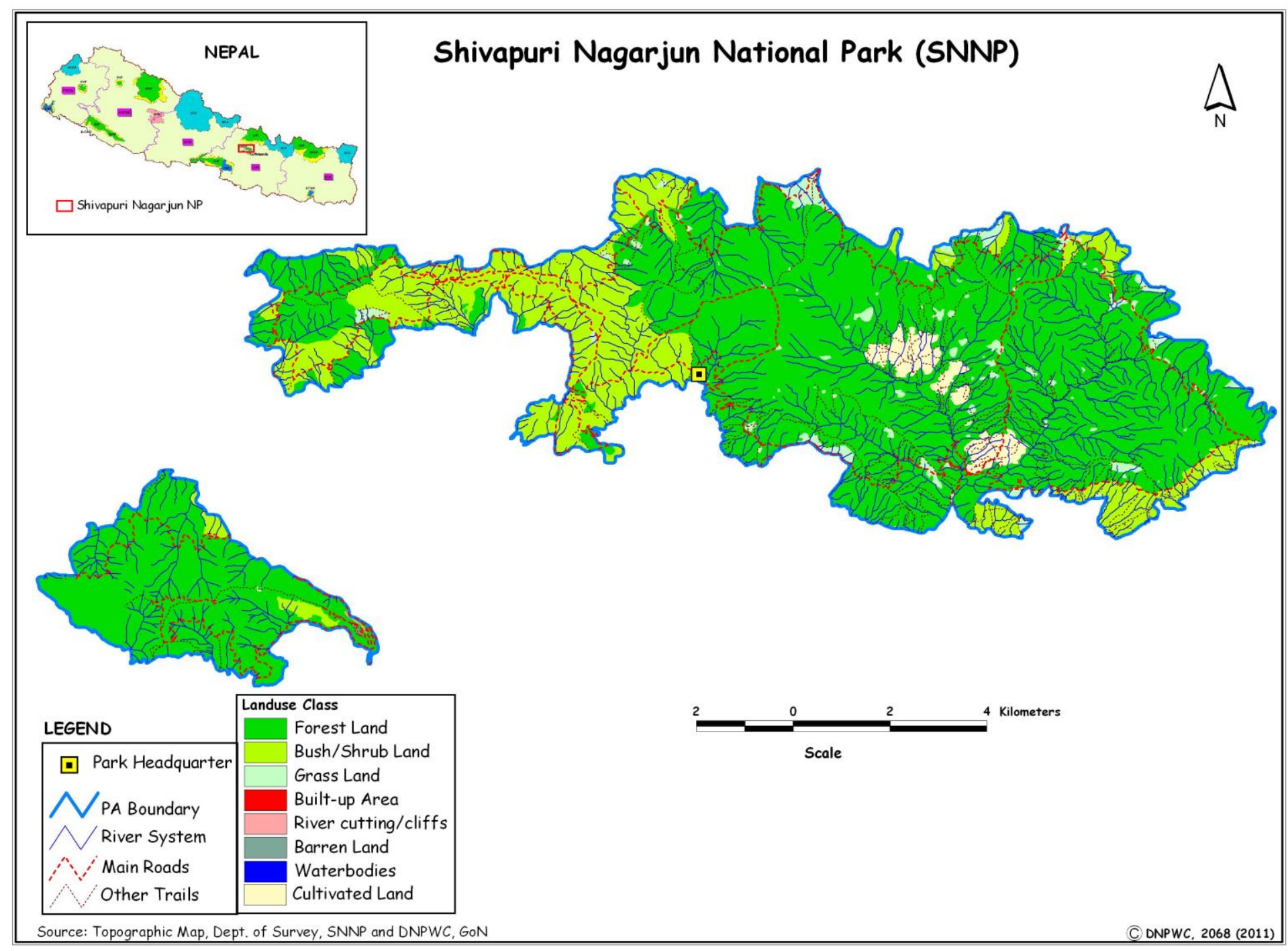


Fig. 2

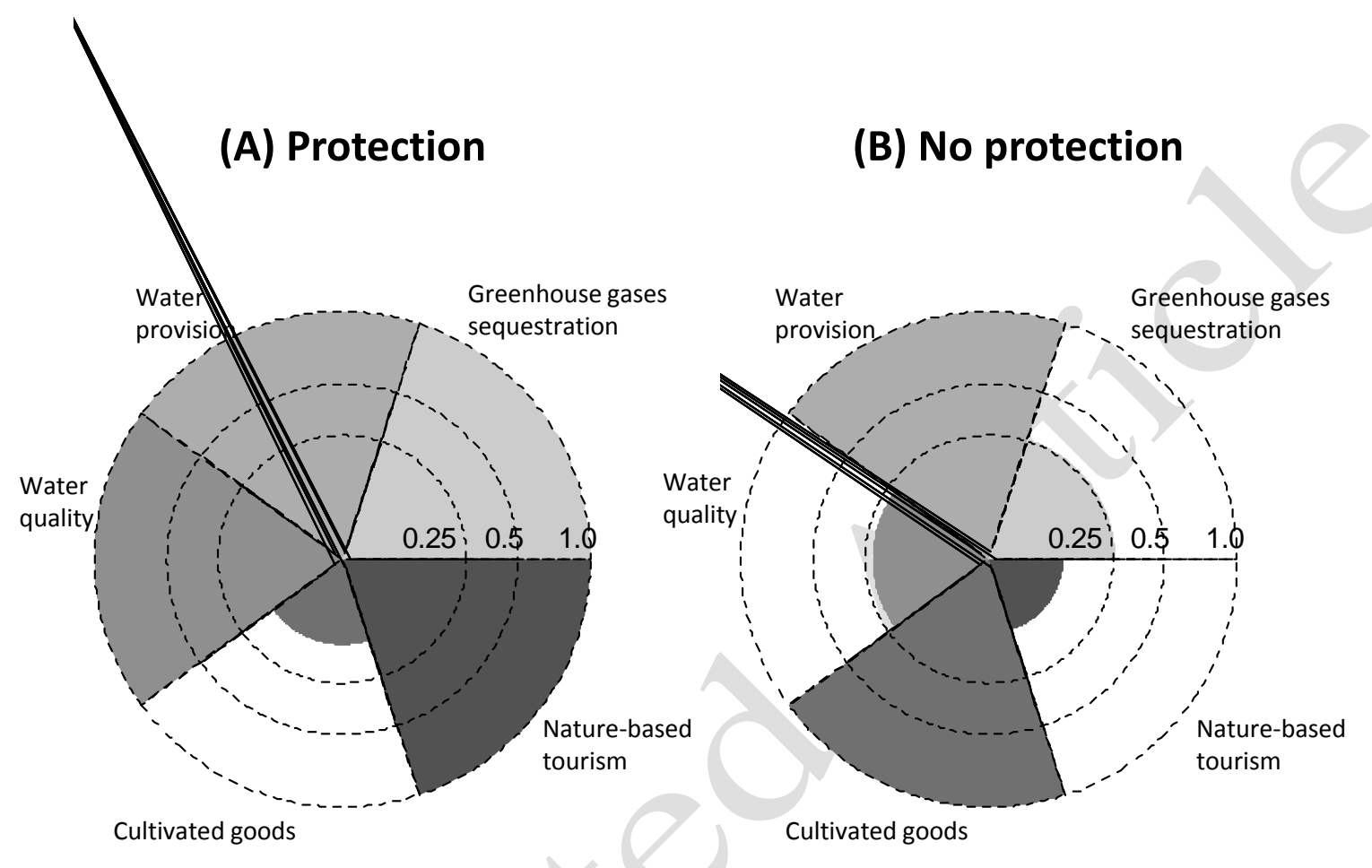

(C) One-off changes in stock

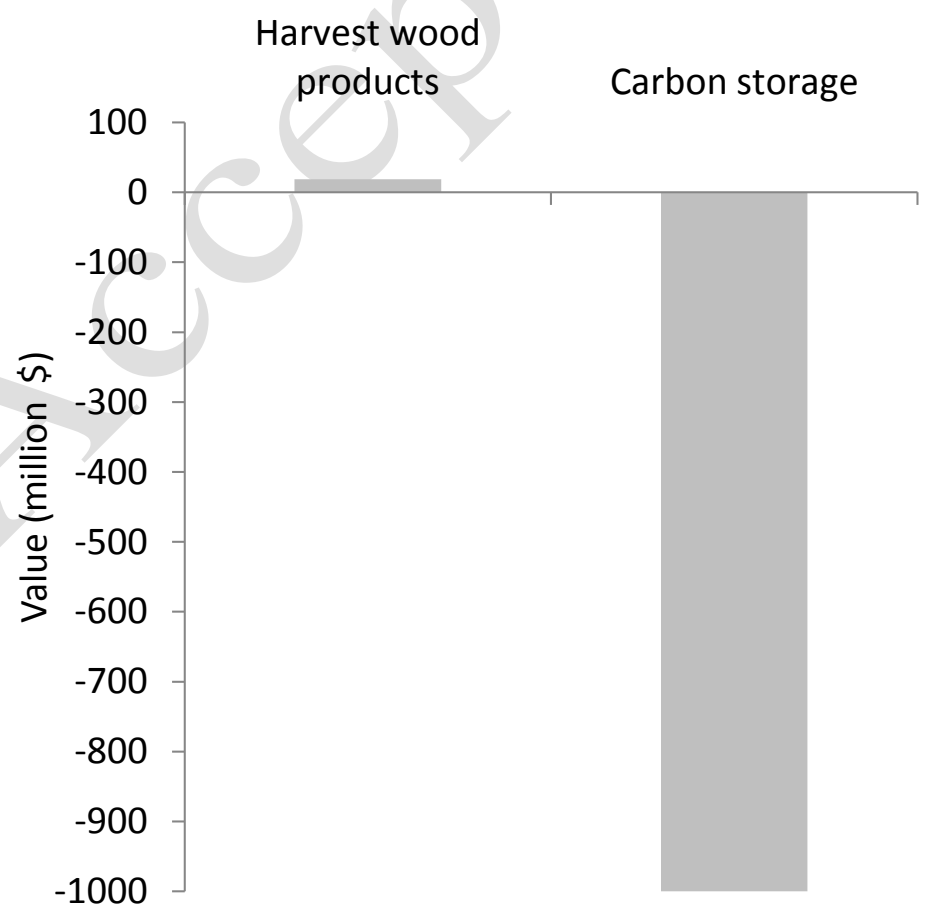


Fig. 3

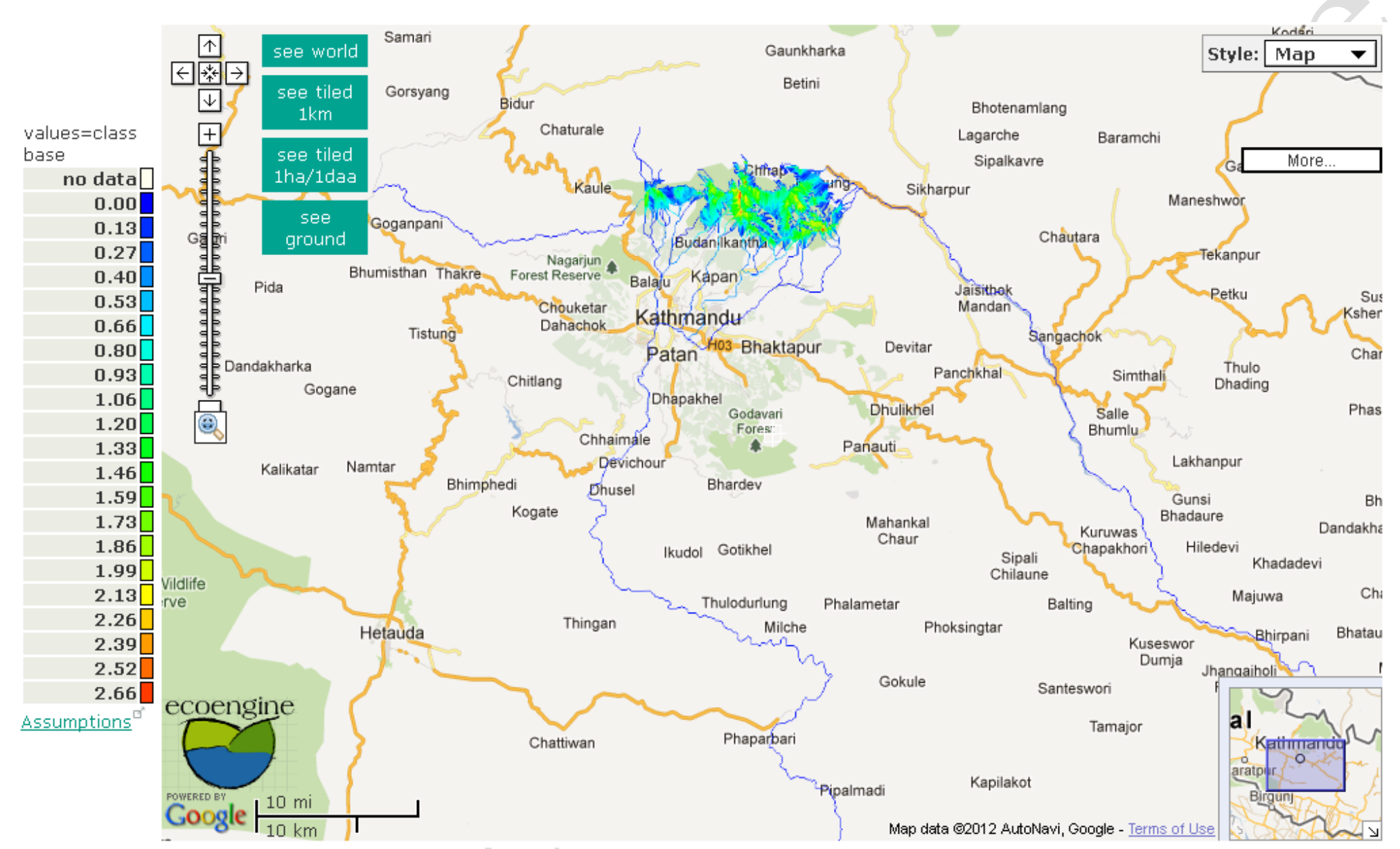

(C) 2012 Google, AutoNavi 


\section{Appendix A. Supplementary material}

\section{Supporting Information S1.}

\section{Methods}

Global climate regulation -To estimate the carbon storage in above-ground biomass (AGB), we stratified the park according to land cover classes: oak-dominated forest; Schima-Castanopsisdominated forest; pine forest; shrubland; grassland; and cropland. In total, we surveyed nine transects in the oak-dominated forest, six transects in the mixed Schima-Castanopsis-dominated forest, and six transects in the pine forest totalling 0.92 ha. We measured diameters at breast height (dbh) following standard protocols (Phillips et al. 2009) for all trees $\geq 10 \mathrm{~cm}$ along $5 \mathrm{~m} \mathrm{x}$ $100 \mathrm{~m}$ stratified-random transects in the Shivapuri block. The AGB of each tree was estimated using regression models developed for temperate forest involving dbh (D):

$$
\begin{aligned}
& \mathrm{AGB}_{\text {oak }}=\exp (-2.0127+2.4342 \times \operatorname{lnD}) \\
& \mathrm{AGB}_{\text {pine }}=0.887+\left(\left(10486 \times \mathrm{D}^{2.84}\right) /\left(\mathrm{D}^{2.84}+376907\right)\right) \\
& \mathrm{AGB}_{\text {general }}=0.5+\left(\left(25000 \times \mathrm{D}^{2.5}\right) /\left(\mathrm{D}^{2.5}+246872\right)\right)
\end{aligned}
$$

Equation 1 was used for Quercus species (Jenkins et al. 2003) and equation 2 for Pinus species (Brown and Schroeder 1999). We used equation (3) for all other tree species (Schroeder et al. 1997). These equations are widely accepted and commonly used in the literature (e.g. Pearson et al. 2005). The amount of carbon stored in a tree was assumed to be $50 \%$ of the above-ground biomass (Chave et al. 2005). To determine sample size, we estimated carbon stocks $\left(\mathrm{Mg} \mathrm{C} \mathrm{ha}^{-1}\right)$, standard deviations and variances from six preliminary transects in each forest type to work out the required number of transects needed to achieve a precision level of $20 \%$ (for the formula, see Pearson et al. 2005). No loss of biomass carbon stocks due to disturbance, such as wood harvesting, charcoal removal and fire, was reported from the park.

The estimates of carbon stocks in AGB for oak-dominated broadleaf forest, Schima-Castanopsis forest and pine forest were measured using data collected on site. The AGB of shrubland, cropland, grassland, and soil were drawn from the IPCC (2006) tier 1 database. The estimates of stored carbon in BGB for all habitats were calculated using a below-ground biomass to above- 
ground biomass ratio (conversion factors) for a particular habitat type (IPCC 2006). The estimates of carbon stocks in litter were calculate using conversion factors from IPCC (2006). The maximum and minimum deadwood carbon stocks in forests and shrubland were estimated by multiplying those of AGB with a conversion factor of 0.1 and 0.4, respectively (Brown 1997, Marklund and Schoene 2006). The estimates of carbon stocks of bare ground and residential areas were assumed to be insignificant. The estimates of stored carbon in soil were drawn from IPCC (2006). The IPCC guidelines suggest a nominal error of $\pm 90 \%$ for soil. Above-ground carbon (and hence BGB) is calculated to a precision of $20 \%$. We used these per hectare values to calculate the carbon storage under the current and alternative state.

Greenhouse gas sequestration rates (carbon dioxide, methane and nitrous oxide flux) for both states were estimated using published data (Anderson-Teixeira and DeLucia 2011). All figures were converted to carbon dioxide equivalents (expressed as tons of carbon dioxide equivalents [Mg CO $\mathrm{Mg}_{2} \mathrm{Eq}$ ) by multiplying tons of gas by the associated global warming potential (GWP): $\mathrm{Mg}$ $\mathrm{CO}_{2} \mathrm{Eq}=$ tons of a greenhouse gas $\times \mathrm{GWP}$, where the GWPs of carbon dioxide, methane and nitrous oxide are 1, 23 and 296, respectively (IPCC, 2006).

To perform the sensitivity analysis of carbon storage and annual greenhouse gas sequestration valuation, we used six carbon prices, adjusted to 2011 based on International Monetary Fund's inflation rates (http://www.imf.org/external/pubs/ft/weo/2012/01/weodata/weorept.aspx) (Table S1).

Hydrological services - Rainwater captured by the park serves the population of 2.5 million people living in the Kathmandu Valley (Government of Nepal, 2011). Field analyses of hydrological ecosystem services and the impact of land use change upon them require sophisticated instrumentation. Such studies require long term measurements in order to account for climate variability and temporal changes in soil and vegetation after land use change. Since this was a rapid assessment, we used the WaterWorld Policy Support System v. 2.4 (hereafter WaterWorld; http://www.policysupport.org/waterworld; Mulligan \& Burke, 2005; Mulligan et al. 2010), a web-based spatial modelling system, to understand the hydrological baseline and the impacts of land use change by combining knowledge of hydrological processes with locally 
specific data for the controlling climate, terrain and vegetation properties. The advantage of WaterWorld is that it is rapid, cheap, spatially detailed, and uses sophisticated process models using the best available global datasets to assess the impacts on water-based ecosystem services of a variety of 'policy options' for land use, at the site scale, for any site globally at a 1-hectare spatial resolution. The model calculates monthly and annual hydrological water balance based on mean climatology representing the last 50 years and land cover at the year 2000. The resulting baseline distribution of water balance varies spatially with climate, landscape and vegetation cover. To assess the impacts of land use change, we applied the plausible alternative state as a land use 'policy option'. WaterWorld then provides a series of output maps and statistics that present the differences between the altered land use and the baseline for the same region. We focused particularly on hydrological ecosystem service outputs for monthly water balance, runoff and soil erosion (as a proxy for water quality).

Cultivated goods - To estimate the average annual agricultural value per ha, we surveyed a total of 8 ha cropland across 23 households which represented $10 \%$ of the total households of Tokha and Budhanilkantha municipalities (94 in Tokha and 129 in Budhanikantha) near the park to find out the quantity and value of cultivated goods from that comparison site (for the questionnaire see Supporting Information S2). Based on variance in annual values of agricultural production reported in the first 15 interviews, we used power analysis to calculate that the minimum sample size needed to estimate annual farm output value to a precision level of $30 \%$ was 23 interviews. We also checked if sample size was adequate by plotting the running means of the annual values of agricultural output per ha.

Nature-based recreation and tourism - We obtained information on the annual total number of tourists visiting the park and the entrance fees charged from the Department of National Parks and Wildlife Conservation, Nepal for the period between June 2009 and June 2010. Visitors were classified into local and international tourists. We also undertook a field survey to collect empirical data on the expenditure of visitors to the park and to determine the importance of the natural features of the park to their decision to visit. Surveys were conducted at two main entrances, initially targeting six local and six international tourists to establish the sample size required to attain a precision level of $20 \%$ for each target group - an adapted methodology from 
Pearson et al. (2005). Interviews included a mixture of fixed response and open-ended questions (see Supporting Information S3). The main objectives of the interview were to determine (1) approximate travel distance to the park; (2) cost of travel and any other costs associated with the trip; and (3) if the visitors would visit the park if $75 \%$ of the forest was converted into farmland and residential areas (the alternative state). The tourism revenue from an international tourist was estimated as the expenditure per day spent during the holiday trip - this includes the costs of air travel to Nepal, accommodation, meals and travel costs within the country divided by the total number of days spent in Nepal - multiplied by the number of days spent at the park. For both visitor types, their average spends were multiplied by the annual total number of visits for that visitor category to the park to estimate their annual contributions to the nature-based recreation value of the park. The annual expenditure on visiting the park was then derived by summing the annual contributions from both national and international visitors, plus the total entrance fees collected for 2011. From this, we subtracted the value from the percentage of visitors who would have still visited in the alternative state in order to estimate the net value of nature-based recreation and tourism for the park.

Conservation costs - Conservation costs were included in the calculation. The sum of conservation/management costs was taken to be the annual park management budget which includes: (1) salaries for permanent staff and army (acting as park rangers); (2) operating costs of running the reserve, e.g. equipment repairs, fuel, casual labour, staff training, reserve monitoring and protection; and (3) capital expenditure - this is the cost of purchasing equipment or facilities, e.g. investing in buildings. The conservation costs also included the budget for employing national army at the park. This data for 2011 was obtained from the park warden who was responsible for administrating the funds.

Farming costs - The assessment of the average net value per hectare took account of revenues, capital costs (e.g. transport, seeds, tools), harvesting, processing and marketing costs. We did not consider family labour as a cost item because (1) there was a constraint in the rural labour market where the unemployment rate was high; (2) members of the agrarian society-where agriculture is a primary mean of support and sustenance-were likely have a preference for "self-employment"; and (3) there were likely high commuting and accommodation costs associated with off-farm 
wage work. However, we considered the shadow wages for hired labour. The value per hectare was then transferred to the area of cropland in the current state (a small area linked to two settlements inside the park) and under the alternative state.

One-off windfall benefit - Economic one-off benefit of harvesting timber and fuelwood during conversion to the alternative state (i.e. no protection) was included in the assessment (Table S3). Oak and pine trees with DBH $24-36 \mathrm{~cm}$ were included in biomass calculations as this was the main range size for harvested timber species. Area of each forest type lost is calculated based on its current proportional area of the site (of the total area of pine and oak forest, $64 \%$ is oak and $36 \%$ pine). Area of forest used for fuelwood is the total area that becomes degraded in the alternative state (for details see Table S3). Wood density conversion was taken from IPCC (2006) as the mean value for Quercus sp. (0.58) and Pinus radiata (mean 0.38). Data on price was obtained from visiting local timber yards and taking the average price for planks of each wood type.

Field work effort - TESSA enabled relatively rapid assessments of the magnitude, monetary values (where appropriate) and distribution of ecosystem services delivered by the park. We spent a total of 316 person-hours collecting the field data. The field work included measuring trees for estimating carbon stock (173 person-hours); and carrying out individual surveys for estimating revenue from nature-based tourism and recreation (74 person-hours), and household interviews for assessing cultivated goods, livestock and harvested wild goods (69 person-hours).

\section{References}

Adhikari, B.S., Rawat, Y.S., Singh, S.P., 1995. Structure and function of high altitude forests of Central Himalaya. I. dry matter dynamics. Ann. Bot. - London. 75, 237-248.

Anderson-Teixeira, K.J., DeLucia, E.H., 2011. The greenhouse gas value of ecosystems. Glob. Change Biol. 17, 425-438.

Baral, S.K., Malla, R., Ranabhat, S., 2010. Above-ground carbon stock assessment in different forest types of Nepal. Banko Janakari 19, 10-14.

Brown S., 1997. Estimating Biomass and Biomass Change of Tropical Forests: A Primer. UN FAO Forestry Paper 134, UN FAO, Rome, pp 55. 
Brown, S. L., Schroeder, P.E., 1999. Spatial patterns of aboveground production and mortality of woody biomass for eastern US forests. Ecol. Appl. 9, 968-980.

Chaturvedi, O.P., Singh, J.S., 1987. The structure and function of Pine forest in Central Himalaya. I. Dry matter dynamics. Ann. Bot. - London 60, 237-252.

Chave, J., Andalo C., Brown, S., Cairns, M.A., Chambers, J.Q., Eamus, D., Folster, H., Fromard, F., Higuchi, N., Kira, T., Lescure, J.P., Nelson, B.W., Ogawa, H., Puig, H., Riera, B., Yamakura, T., 2005. Tree allometry and improved estimation of carbon stocks and balance in tropical forests. Oecologia 145, 87-99.

Greenspan Bell, R, Callan, D., 2011. More than Meets the Eye: The Social Cost of Carbon in U.S. Climate Policy in Plain English. Policy Brief. World Resources Institute, Washington DC.

Government of Nepal, 2011. Preliminary population census results. Government of Nepal, Kathmandu

Interagency Working Group on Social Cost of Carbon, 2013. Technical Update of the Social Cost of Carbon for Regulatory Impact Analysis Under Executive Order 12866. Revised July 2015. Interagency Working Group on Social Cost of Carbon, United States Government.

Jenkins, J.C., Chojnacky, D.C., Heath, L.S., Birdsey, R.A., 2003. National-scale biomassestimators for United States tree species. Forest Sci. 49, 12-35.

Juffe-Bignoli, D., Burgess, N.D., Bingham, H., Belle, E.M.S., de Lima, M.G., Deguignet, M., Bertzky, B., Milam, A.N., Martinez-Lopez, J., Lewis. E., Eassom, A., Wicander, S., Geldmann, J., van Soesbergen, A., Arnell, A.P., O’Connor, B., Park, S., Shi, Y.N., Danks, F.S., MacSharry, B., Kington, N., 2014. Protected Planet Report 2014. UNEP WCMC, Cambridge.

Marklund, L.G. and Schoene D., 2006. Global Forest Resources Assessment 2005. Global Assessment of Growing Stock, Biomass and Carbon Stock. Forestry Department, FAO, Rome.

Mulligan, M., Burke, S.M., 2005. FIESTA: Fog Interception for the Enhancement of Streamflow in Tropical Areas. Report to UK DFID, 174

Mulligan, M., Rubiano, J., Hyman, G., White, D., Garcia, J., Saravia, M., Leon, J.G., Selvaraj, J.J., Gutierrez, T., Saenz-Cruz, L.L., 2010. The Andes 'basin': biophysical and developmental diversity in a climate of change. Water Int. 35, 472-492.

Pearson, T., Walker, S.,Brown, S., 2005. Sourcebook for land use, land-use change and forestry projects. Winrock International. http://www.planvivo.org/wp-

content/uploads/LULUCF_Sourcebook_compressed11.pdf. Accessed 28 June 2014

Peters-Stanley, M, Hamilton, K, Marcello, T, Sjardin, M., 2011. Back to the Future: State of the Voluntary Carbon Markets 2011. Ecosystem Marketplace Bloom New Energy 
Finance. https://www.greenbiz.com/sites/default/files/state-voluntary-carbon-offsets-2011.pdf. Accessed on 28 June 2014

Phillips, O., Bakers T. Feldpausch, T., Brienen, R., 2009. RAINFOR field manual for plot establishment and remeasurement. RAINFOR Amazon forest inventory. http://www.rainfor.org/en/manuals Accessed on 22 March 2015

Point Carbon, 2012. Volume of carbon traded in 2011 grew 19\%, bucking downturn. http://www.pointcarbon.com/aboutus/pressroom/pressreleases/1.1714530. Accessed on 28 June 2014

Schroeder, P., Brown, S,, Mo, J.M., Birdsey, R., Cieszewski, C., 1997. Biomass estimation fortemperate broadleaf forests of the United States using inventory data. Forest Sci. 43, 424-434.

Shrestha, B.P., 2009. Carbon sequestration in Schima-Castanopsis forest: a case study from Palpadistrict. The Greenery 7, 34-40.

Stern, N.H., Peters, S., Bakhshi, V., Bowen, A., Cameron, C., Catovsky, S., Crane, D., Cruickshank, S., Dietz, S., Edmonson, N., Garbett, S.-L., Hamid, L., Hoffman, G., Ingram, D., Jones, B., Patmore, N., Radcliffe, H., Sathiyarajah, R., Stock, M., Taylor, C., Vernon, T., Wanjie, H., Zenghelis, D., 2006. Stern review: the economics of climate change, Cambridge University Press, Cambridge, UK http://webarchive.nationalarchives.gov.uk/+/http:/www.hmtreasury.gov.uk/sternreview_index.htm. Accessed on 28 June 2014

Subedi, M.N., 2004. Above ground biomass of Quercus semecarpifolia Sm. forest surveyed on natural and semi-natural stands in Nepal. Indian Forester 130, 858-866.

Tol, R.S.J., 2010. The costs and benefits of EU climate policy for 2020. Copenhagen Consensus Center. http://www.copenhagenconsensus.com/sites/default/files/cccTolPaper.pdf. Accessed on 28 June 2014

Whitton, Z., Tilbury, J., 2014. The social cost of carbon: a review for corporate decision makers. Veratas. 
Supporting Information S2. Household interview questions for assessing cultivated goods, livestock and harvested wild goods.

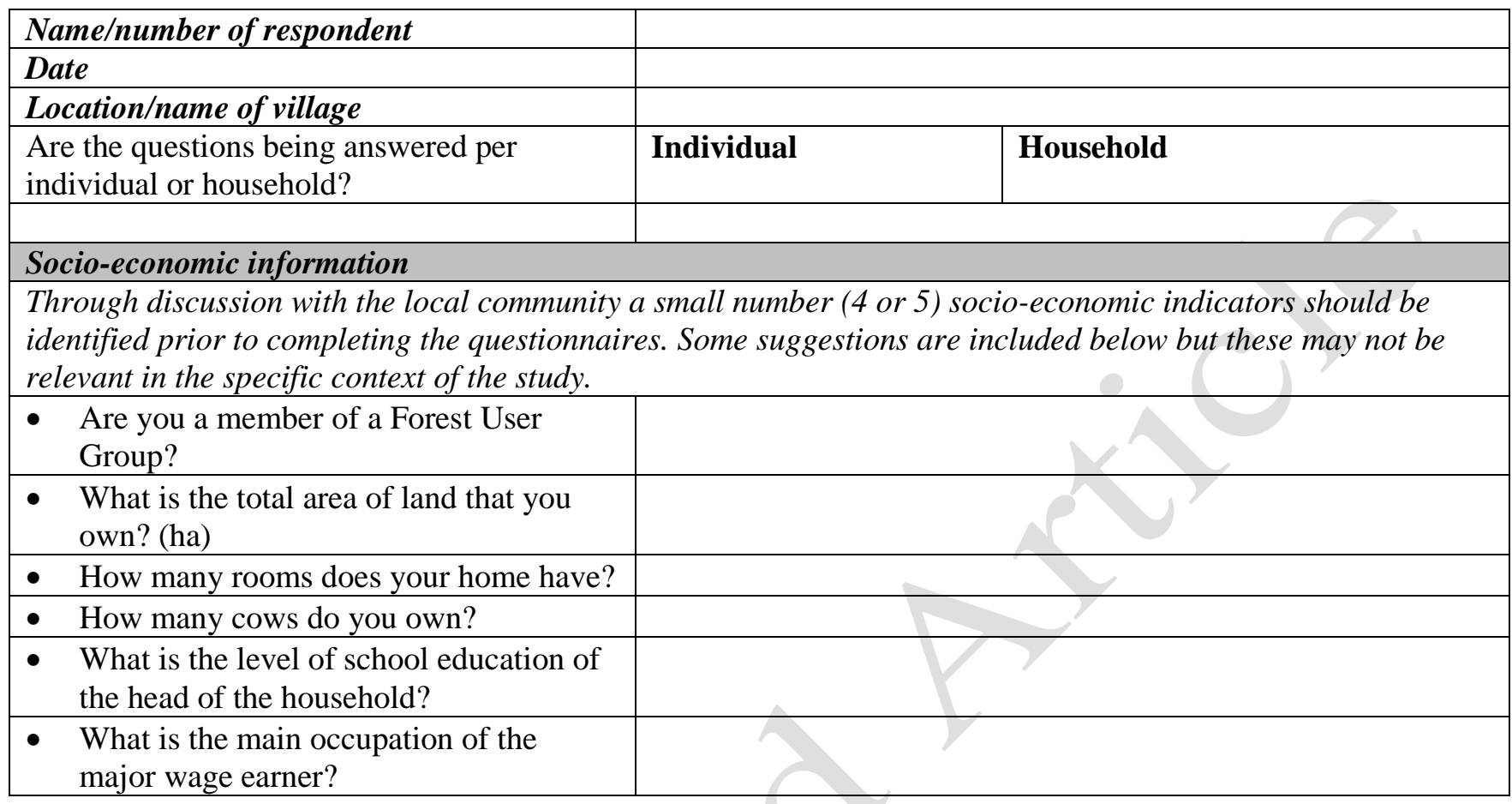

\section{Cultivated goods}

It is important here that you only focus on the main crops or products from their fields. If they have a very small patch growing something that has a low economic value then it is not worth including this

What is your total farm size (use

local units of area if appropriate):

How many fields do you have?

\begin{tabular}{|c|c|c|c|}
\hline $\begin{array}{l}\text { What are the top three most important } \\
\text { crops that you grow? }\end{array}$ & 1. & 2. & 3. \\
\hline Unit $\bigcirc$ & & & \\
\hline Average price obtained per unit* $\mathbf{0}$ & & & \\
\hline Percentage for own use & $\%$ & $\%$ & $\%$ \\
\hline Percentage sold/ bartered & $\%$ & $\%$ & $\%$ \\
\hline $\begin{array}{l}\text { Daily wage rate that family members } \\
\text { could earn doing alternative work on } \\
\text { days spent } \\
\text { cultivating/harvesting/processing }\end{array}$ & & & \\
\hline Daily wage rate of hired labour & & & \\
\hline $\begin{array}{l}\text { If the crop is a perennial crop (e.g. } \\
\text { fruit trees, vines, nut bushes, } \\
\text { perennial herbs) ask the following: }\end{array}$ & & & \\
\hline $\begin{array}{l}\text { How much did it cost to establish the } \\
\text { crop (e.g. plants, stakes, labour etc.) }\end{array}$ & & & \\
\hline
\end{tabular}


Complete the following, using a separate row for each field.

Notes:

- For each crop, record the details in all columns so that these can be summed. If there are several crops grown in one field please record full details for up to a maximum of 3 per field

- If there is any crop residue collected for fodder, also complete the annual time taken and cost of labour for collecting this fodder

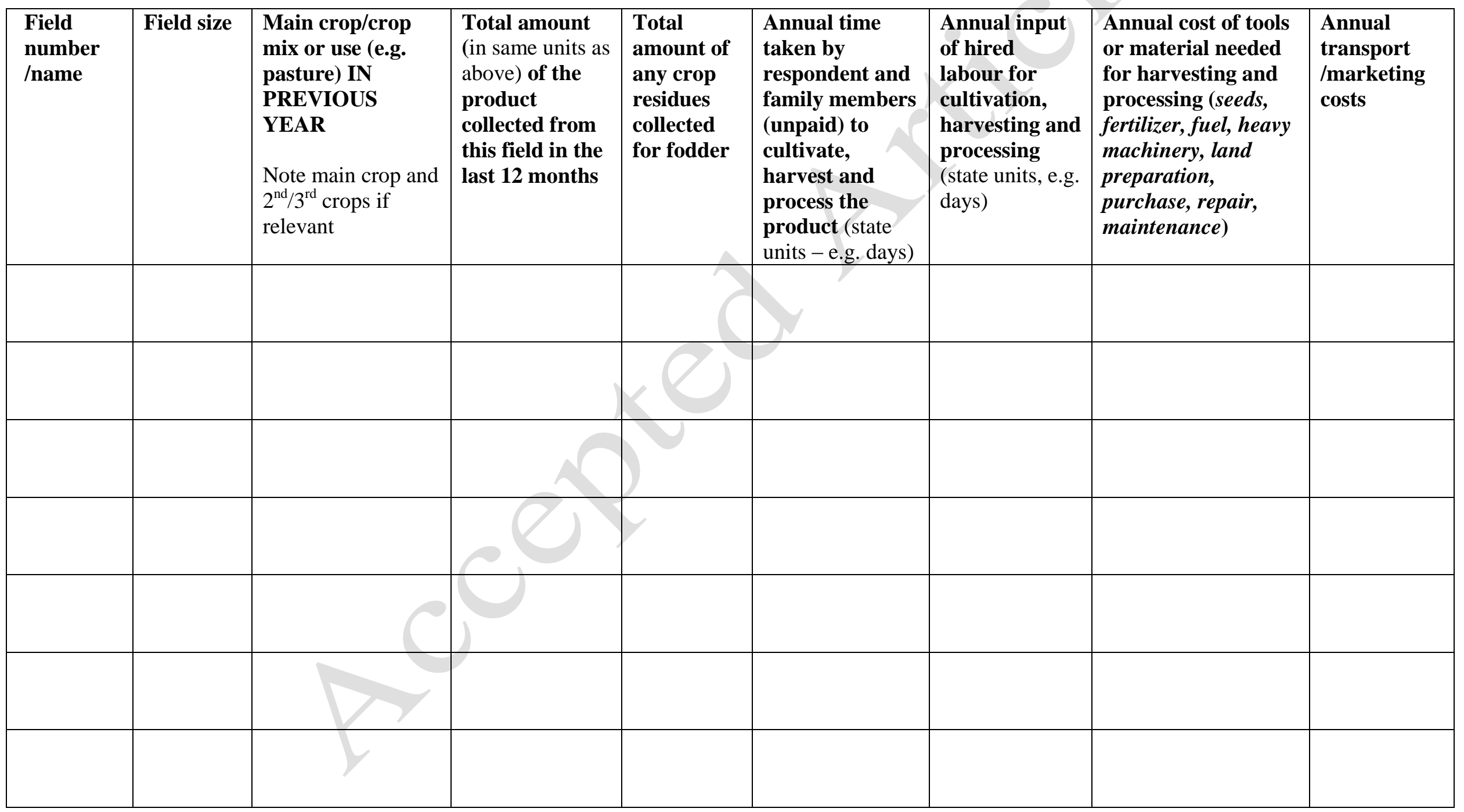


- If there is no livestock then just circle 'no' for this table and continue

- If they do have livestock, record details for up to a maximum of three types - based on the order of importance.

- You do not have to record three types if, for example they only have cows, just record the details for them

\section{Livestock}

It is important to find out the value of livestock as a contribution to cultivated goods. The value of livestock is determined from the value of the fodder that is used to feed them

Do you have any livestock on your land?

If yes, what?

How many?

Total area of land used for grazing

*This can be calculated from the area of fields

mentioned above as being 'pasture'

Do you buy fodder or use your own land to supply it?

Total weight/volume of fodder taken from your own land annually to feed the livestock

*This can be compared to the amount declared above

Total weight/volume of fodder purchased annually to feed the livestock

Cost of buying fodder (per unit or to supply

animals for the whole year)

Per hectare value of cultivated feed (from total

weight $\mathrm{x}$ price)

\begin{tabular}{|l|l|l|}
\hline \multicolumn{2}{|l|}{ No } & 3. \\
\hline & & \\
\hline & & \\
\hline & & \\
\hline & \\
\hline & \\
\hline & \\
\hline
\end{tabular}


- If there is no HWG then just circle 'no' for this table and continue

- If they do harvest wild goods, record details for up to a maximum of three types - based on the order of importance.

- You do not have to record three types if, for example they only harvest one product, just record the details for that.

- If the harvest is of extremely low value or importance, please note what that product is but it is not necessary to record the value data if you consider it to be insignificant.

\section{Harvested wild goods}

It is important to find out if any wild goods are used from the farmland. Focus on the top three most important goods.

Do you harvest any wild goods from your farm land

(including hedgerows, field trees, field borders)?

If yes, which wild goods do you harvest from your

1.

2.

farmland? List them in order of importance.

\section{For those products of significant value, complete the following (complete a separate form for each wild harvested product)}

\section{Quantity and value of product}

Total quantity collected from the site in last 12

months 0

Unit $\bullet$

Percentage for own use

Percentage sold/ bartered

Average price obtained per unit*

\section{Family labour}

Annual time taken by respondent and family members (unpaid) to harvest and process the product (state units - e.g. days)

Daily wage rate that these family members could earn doing alternative work on days spent

harvesting/processing

\section{Hired labour}

Annual input of hired labour for harvesting and processing (state units, e.g. days) Daily wage rate of hired labour

\section{Other costs}

Annual cost of tools or material needed for harvesting and processing (purchase, repair, maintenance)

Annual transport/marketing costs

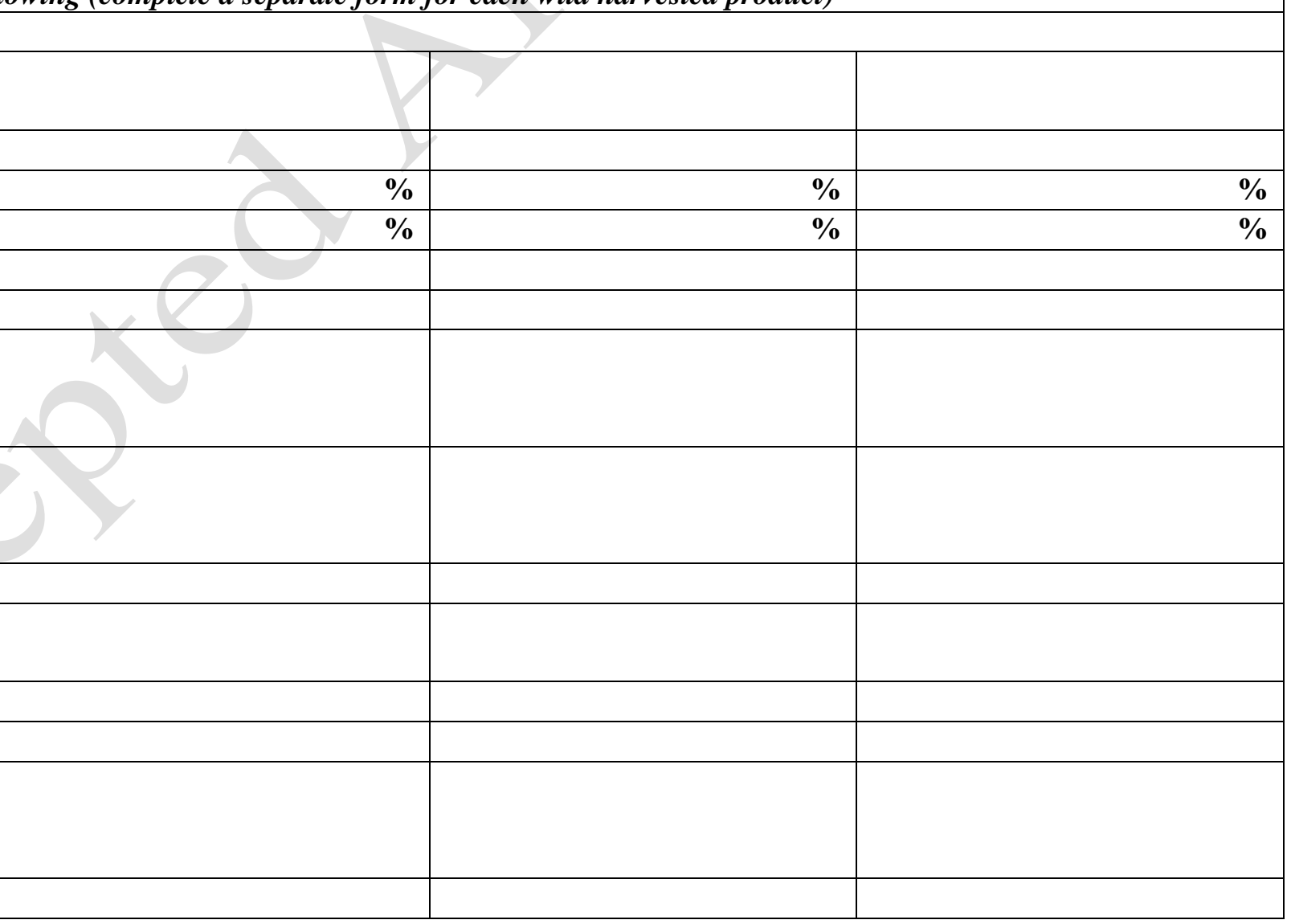


Supporting Information S3. Interview questions for visitors at Shivapuri-Nagarjun National

Park.

\begin{tabular}{|c|c|}
\hline \multicolumn{2}{|l|}{ Site name/Location interviewed: } \\
\hline \multicolumn{2}{|l|}{ Date/Time: } \\
\hline \multicolumn{2}{|l|}{ Respondent number: } \\
\hline \multicolumn{2}{|c|}{ 1. Mode of Transport: Walk/Car/Bus/Motorcycle/Bicycle/Others(please specify) } \\
\hline \multicolumn{2}{|c|}{ 2. Type: National day-tripper/Domestic tourist/International tourist } \\
\hline $\begin{array}{l}\text { 3. If applicable, how many persons in the travel } \\
\text { group? }\end{array}$ & $\begin{array}{l}\text { Number of adults } \\
\text { Number of children (under } 5 \text { ) }\end{array}$ \\
\hline 4. Where are you from? & $\begin{array}{l}\text { For national day-trippers and domestic } \\
\text { tourists: } \\
\text { Indicate which town/city: } \\
\text { Within } 10 \mathrm{~km} \text { of this site } \square \\
\text { Within } 25 \mathrm{~km} \text { of this site } \\
\text { More than } 25 \mathrm{~km} \text { of this site } \\
\text { For international tourists: } \\
\text { Indicate which country: }\end{array}$ \\
\hline $\begin{array}{l}\text { 5. Did you pay an entrance fee/permit to enter this } \\
\text { site? (state currency) }\end{array}$ & $\begin{array}{l}\text { Yes } \square \text { No } \square \\
\text { If yes, how much } \quad \text { (indicate per person or } \\
\text { for the whole group) }\end{array}$ \\
\hline $\begin{array}{l}\text { 6. How much have you spent/do you expect to spend } \\
\text { in relation to this trip? } \\
\text { For each: } \\
\text { - state currency } \\
\text { - indicate per person or for the whole group } \\
\text { - indicate whether the suppliers are local }(<10 \mathrm{~km}) \text { or } \\
\text { no-local }(>10 \mathrm{~km}) \text {. For example, a taxi/bus ride from } \\
\text { Kathmandu is non-local, but the food/drinks bought at } \\
\text { the stall outside the national park is local }\end{array}$ & $\begin{array}{l}\text { Transport (e.g. petrol cost, bus fares etc; include } \\
\text { return trip) } \\
\text { Food/drinks } \\
\text { Travel guides } \\
\text { Souvenirs } \\
\text { Offerings (e.g. flowers or incenses for } \\
\text { temples/shrines) } \\
\text { Others (please specify) }\end{array}$ \\
\hline \multicolumn{2}{|c|}{ Questions $7-10$ for International tourists and domestic tourists only } \\
\hline \multicolumn{2}{|l|}{$\begin{array}{l}\text { 7. How many nights will you spend away from home } \\
\text { whilst on this whole trip? }\end{array}$} \\
\hline $\begin{array}{l}\text { 8. Have you spent/do you plan to spend any nights at } \\
\text { or near (less than } 10 \mathrm{~km} \text { ) this site? }\end{array}$ & $\begin{array}{l}\text { Yes } \square \text { No } \square \\
\text { If Yes, state: } \\
\text { (1) Number of nights at or near this site: } \\
\text { (2) Type of accommodation: Stay with } \\
\text { friends/Hotel/Temple/Other(please specify) } \\
\text { (3) How much is the room rate per night: }\end{array}$ \\
\hline $\begin{array}{l}\text { 9. In total, how much money do you expect to spend } \\
\text { during your whole trip (state currency) }\end{array}$ & $\begin{array}{l}\text { Estimate } \\
\text { whole group) }\end{array}$ \\
\hline \multicolumn{2}{|l|}{$\begin{array}{l}\text { 10. How many days will you spend at this site during } \\
\text { your whole trip? }\end{array}$} \\
\hline $\begin{array}{l}\text { 11. Would you come for these activities if about } \mathbf{7 5 \%} \\
\text { of the forest is converted into farmland and } \\
\text { residential areas? } \\
\text { Describe the alternative state (accompany with a } \\
\text { photograph representing this state) } \\
\text { The farmland and residential areas near the entrance of } \\
\text { the site can represent the alternative state. Note that } \\
\text { the temples/shrines remain unchanged. }\end{array}$ & Yes $\square \quad$ No $\square$ \\
\hline
\end{tabular}


Table S1. Carbon prices - adjusted to 2011 - used for the sensitivity analysis of (A) carbon storage and (B) annual greenhouse gas sequestration valuation. Prices are expressed in US dollars. For the carbon stock, the difference between the current state (protection) and the most plausible alternative state (no protection) is the one-off value of the avoided carbon loss if there is a lack of protection. Carbon prices were adjusted to 2011 based on International Monetary Fund's inflation rates.

\begin{tabular}{|c|c|c|c|}
\hline \multirow[t]{2}{*}{ Source } & \multirow{2}{*}{$\begin{array}{r}\$ \mathrm{MgC} \\
\text { (adjusted to } \\
2011 \text { ) }\end{array}$} & \multicolumn{2}{|l|}{ C storage \$ } \\
\hline & & Protection & No protection \\
\hline 2011 UK Government (Whitton and Tilbury, 2014) & 414.71 & $2,017,200,103$ & $804,890,947$ \\
\hline 2015 US Government (Interagency Working Group on Social Cost of Carbon, 2013) & 358.38 & $1,743,182,213$ & $695,553,991$ \\
\hline 2011 EU Emission Trading Scheme (Point Carbon, 2012) & 56.18 & $273,266,383$ & $109,037,094$ \\
\hline 2011 Verified Emission Reductions (Peters-Stanley et al., 2011) & 22.75 & $110,658,779$ & $44,154,395$ \\
\hline \multicolumn{4}{|l|}{ Earlier set of social carbon cost estimates } \\
\hline Stern et al. (2006) & 348.13 & $1,693,346,849$ & $675,668,986$ \\
\hline 2009 UK Government (Greenspan Bell and Callan, 2011) & 319.33 & $1,553,260,131$ & $619,772,434$ \\
\hline 2010 US Government (Greenspan Bell and Callan, 2011) & 264.80 & $1,288,017,968$ & $513,937,115$ \\
\hline Tol (2010) & 118.09 & $574,404,186$ & $229,195,274$ \\
\hline
\end{tabular}

(B)

\begin{tabular}{|c|c|c|c|}
\hline \multirow[t]{2}{*}{ Source } & \multirow{2}{*}{$\begin{array}{r}\$ \mathrm{Mg} \mathrm{CO}_{2} \mathrm{eq}^{-1} \\
\text { (adjusted to } \\
\text { 2011) }\end{array}$} & \multicolumn{2}{|c|}{ Greenhouse gases sequestration $\$ \mathrm{y}^{-1}$} \\
\hline & & Protection & No protection \\
\hline 2011 UK Government (Whitton and Tilbury, 2014) & 113.00 & $10,908,926$ & $2,861,469$ \\
\hline 2015 US Government (Interagency Working Group on Social Cost of Carbon, 2013) & 97.65 & $9,427,050$ & $2,472,765$ \\
\hline 2011 EU Emission Trading Scheme (Point Carbon, 2012) & 15.31 & $1,478,015$ & 387,691 \\
\hline 2011 Verified Emission Reductions (Peters-Stanley et al., 2011) & 6.20 & 598,543 & 157,001 \\
\hline
\end{tabular}

Earlier set of social carbon cost estimates 
Stern et al. (2006)

2009 UK Government (Greenspan Bell and Callan, 2011)

2010 US Government (Greenspan Bell and Callan, 2011)

Tol (2010)
94.86

87.01

72.15

32.18
$9,157,706$

$8,399,873$

$6,965,542$

$3,106,630$
$2,402,114$

$2,203,331$

$1,827,098$

814,886 
Table S2. Estimated monetary one-off benefit of harvesting wood products during conversion to the alternative state (i.e. no protection).

\begin{tabular}{|c|c|c|c|c|c|c|c|c|c|}
\hline $\begin{array}{l}\text { Source of wood product (above- } \\
\text { ground living biomass) }\end{array}$ & $\begin{array}{l}\text { Biomass } \\
\text { (Mg/ha) }\end{array}$ & $\begin{array}{l}\text { Area } \\
(\text { ha })^{c}\end{array}$ & $\begin{array}{c}\text { Total } \\
\text { biomass } \\
(\mathrm{Mg})\end{array}$ & $\begin{array}{l}\text { Wood } \\
\text { Density } \\
\left(\mathrm{Mg} / \mathrm{m}^{3}\right)^{\mathrm{d}}\end{array}$ & $\begin{array}{c}\text { Biomass } \\
\text { conversion } \\
\text { expansion } \\
\text { factor }(\mathrm{BCEF})^{\mathrm{e}}\end{array}$ & $\begin{array}{l}\text { Merchantable } \\
\text { growing stock } \\
\text { volume }\left(\mathrm{m}^{3}\right)\end{array}$ & $\begin{array}{l}\text { Price } \\
\left(\$ / \mathrm{m}^{3}\right)^{\mathrm{f}}\end{array}$ & $\begin{array}{l}\text { Costs } \\
\left(\$ / \mathrm{m}^{3}\right)\end{array}$ & Total value (\$) \\
\hline Oak-dominated broadleaf forest $^{a}$ & $23^{\mathrm{b}}$ & 5,155 & 118,565 & 0.58 & & 68,768 & 342 & 85 & $17,673,299$ \\
\hline Pine forest (Pinus roxburghii) ${ }^{\mathrm{a}}$ & $18^{\mathrm{b}}$ & 536 & 9,648 & 0.38 & & 3,666 & 342 & 85 & 942,224 \\
\hline \multicolumn{10}{|l|}{ Fuelwood removal } \\
\hline Oak-dominated broadleaf forest & 37 & 5,155 & 190,735 & - & 3.33 & 57,278 & 0.13 & 0 & 7,446 \\
\hline Pine forest & 32 & 536 & 17,152 & - & 3.33 & 5,151 & 0.13 & 0 & 670 \\
\hline \multirow[t]{2}{*}{ Schima-Castanopsis forest } & 37 & 4,238 & 156,806 & - & 3.33 & 47,089 & 0.13 & 0 & 6,122 \\
\hline & & & & & & & & & $18,629,761$ \\
\hline
\end{tabular}

${ }^{a}$ Oak and pine are used for felling according to the Nepalese tree field guide (Discovering Trees in Nepal and the Himalayas by Adrian and Jimmie Storrs published by Sahayogi Press, Kathmandu in 1984)

${ }^{\mathrm{b}}$ Only trees with DBH $24-36 \mathrm{~cm}$ were included in biomass calculations as per local timber yards reporting that this was the main range size for harvested timber species

${ }^{c}$ Area of each forest type lost is calculated based on its current proportional area of the site (of the total area of pine and oak forest, $64 \%$ is oak and $36 \%$ pine). Area of forest used for fuelwood is the total area that becomes degraded in the alternative state.

${ }^{\mathrm{d}}$ Wood density conversion is taken from IPCC 2006 Table 4.14 as the mean value for Quercus sp. (0.58) and Pinus radiata (mean $0.38)$

${ }^{\mathrm{e}} \mathrm{BCEF}$ is taken from IPCC 2006 Table 4.5 as the value for temperate hardwoods $<20 \mathrm{~m}^{3}$ growing stock level

${ }^{\mathrm{f}}$ Data on price obtained from visiting local timber yards and taking the average price for planks of each wood type. 
Table S3. Carbon storage in above-ground living biomass in oak-dominated forest, Schima-Castanopsis forest and pine forest was estimated using field surveys. The estimates of these habitats were within the estimated ranges provided by either IPCC standard table or the primary literature for similar sites. Our estimates of shrubland and grassland were derived from the IPCC standard table.

\begin{tabular}{|c|c|c|c|c|c|}
\hline Habitat type & IPCC classification & $\begin{array}{c}\text { Aboveground } \\
\text { (C Mg/ha) }\end{array}$ & $\begin{array}{c}\text { IPCC } \\
\text { (C } \\
\mathrm{Mg} / \mathrm{ha}) \\
\end{array}$ & $\begin{array}{l}\text { Literature } \\
\text { (C Mg/ha) }\end{array}$ & References \\
\hline Oak-dominated forest & Temperate broadleaf forest & 284 & $10-300$ & $179-297$ & Adhikari et al., 1995; Subedi, 2004 \\
\hline Schima-Castenopsis forest & Subtropical broadleaf forest & 57 & $50-220$ & $34-41$ & Baral et al., 2010; Shrestha, 2009 \\
\hline Pine forest & Temperate needleleaf forest & 52 & $15-40$ & $39-142$ & Baral et al., 2010; Chaturvedi and Singh, 1987 \\
\hline Shrubland & Temperate shrubland & & 24 & & \\
\hline Grassland & Temperate grassland & & 1 & & \\
\hline
\end{tabular}


Table S4. Estimates of carbon stored and greenhouse gas fluxes of various habitat types in the current state (with protection) and the alternative state (no protection) of the Shivapuri-Nagarjun National Park. AGB, BGB, dead, $\mathrm{SOM}, \mathrm{CO}_{2}, \mathrm{CH}_{4}$ and $\mathrm{NH}_{4}$ denote above-ground biomass, below-ground biomass, dead wood, soil organic matter, carbon dioxide, methane and nitrous oxide, respectively. Negative values indicate greenhouse gas emission by the habitats. For soil, the IPCC guidelines suggest a nominal error of $\pm 90 \%$. Above-ground carbon is calculated to a precision of $20 \%$. The maximum and minimum litter and deadwood carbon stocks in forests and shrubland were estimated by multiplying those of AGB with conversion factors derived from Brown (1997), IPCC (2006) and Marklund and Schoene (2006). Potential range is the maximum and minimum estimates, summed across the five carbon pools.

\begin{tabular}{|c|c|c|c|c|c|c|c|c|c|c|c|c|c|}
\hline \multirow[t]{2}{*}{ State } & \multirow[t]{2}{*}{ Habitat type } & \multirow{2}{*}{$\begin{array}{c}\text { Habitat } \\
\text { coverage } \\
(\%)\end{array}$} & \multicolumn{7}{|c|}{ Carbon storage (Mg) } & \multicolumn{4}{|c|}{ Greenhouse gas sequestration $\left(\mathrm{Mg} \mathrm{CO}_{2}\right.$ eq $\left.^{-1}\right)$} \\
\hline & & & AGB & BGB & Litter & Dead & SOM & Total & Potential range & $\mathrm{CO}_{2}$ & $\mathrm{CH}_{4}$ & $\mathrm{~N}_{2} \mathrm{O}$ & Total \\
\hline \multirow[t]{9}{*}{ Protection } & $\begin{array}{l}\text { Oak-dominated } \\
\text { broadleaf forest }\end{array}$ & 45 & $2,016,914$ & 605,074 & 100,846 & 806,766 & 241,785 & $3,771,384$ & & 48,499 & 602 & $-2,408$ & 46,693 \\
\hline & $\begin{array}{l}\text { Schima-Castanopsis } \\
\text { forest }\end{array}$ & 33 & 300,153 & 90,046 & 15,008 & 120,061 & 178,444 & 703,712 & & 35,794 & 444 & $-1,777$ & 34,461 \\
\hline & Pine forest & 5 & 39,105 & 11,340 & 1,955 & 15,642 & 25,643 & 93,686 & & 5,144 & 64 & -255 & 4,952 \\
\hline & Shrubland & 12 & 46,410 & 129,949 & 2,321 & 18,564 & 65,748 & 262,991 & & 11,997 & 135 & -327 & 11,805 \\
\hline & Cropland & 5 & 886 & 2,482 & - & - & 26,207 & 29,575 & & - & 37 & $-1,516$ & $-1,479$ \\
\hline & Grassland & 0 & - & - & - & - & 2,643 & 2,643 & & 116 & 4 & -13 & 107 \\
\hline & Bareground & 0 & - & - & - & - & 131 & 131 & & - & - & 0 & 0 \\
\hline & Urban & 0 & - & - & - & - & - & - & & - & - & 0 & 0 \\
\hline & Total & & $2,403,469$ & 838,891 & 120,129 & 961,033 & 540,600 & $4,864,122$ & $\begin{array}{r}3,512,878- \\
6,215,367\end{array}$ & 101,550 & 1,286 & $-6,297$ & 96,539 \\
\hline \multirow[t]{9}{*}{$\begin{array}{l}\text { No } \\
\text { protection }\end{array}$} & $\begin{array}{l}\text { Oak-dominated } \\
\text { broadleaf forest }\end{array}$ & 12 & 554,855 & 166,457 & 27,743 & 221,942 & 66,515 & $1,037,512$ & & 13,342 & 166 & -662 & 12,845 \\
\hline & $\begin{array}{l}\text { Schima-Castanopsis } \\
\text { forest }\end{array}$ & 6 & 57,807 & 17,342 & 2,890 & 23,123 & 34,367 & 135,530 & & 6,894 & 86 & -342 & 6,637 \\
\hline & Pine forest & 1 & 11,326 & 3,285 & 566 & 4,530 & 7,427 & 27,134 & & 1,490 & 18 & -74 & 1,434 \\
\hline & Shrubland & 17 & 65,885 & 184,477 & 3,294 & 26,354 & 93,336 & 373,346 & & 17,031 & 192 & -465 & 16,758 \\
\hline & Cropland & 41 & 7,467 & 20,909 & - & - & 220,776 & 249,152 & & - & 311 & $-12,770$ & $-12,459$ \\
\hline & Grassland & 0 & - & - & - & - & 2,643 & 2,643 & & 116 & 4 & -13 & 107 \\
\hline & Bareground & 0 & - & - & - & - & 131 & 131 & & - & - & 0 & 0 \\
\hline & Urban & 21 & - & - & - & - & 115,405 & 115,405 & & - & - & 0 & 0 \\
\hline & Total & & 697,341 & 392,469 & 34,494 & 275,949 & 540,600 & $1,940,853$ & $\begin{array}{r}1,174,262- \\
2,707,443 \\
\end{array}$ & 38,873 & 777 & $-14,327$ & 25,323 \\
\hline
\end{tabular}




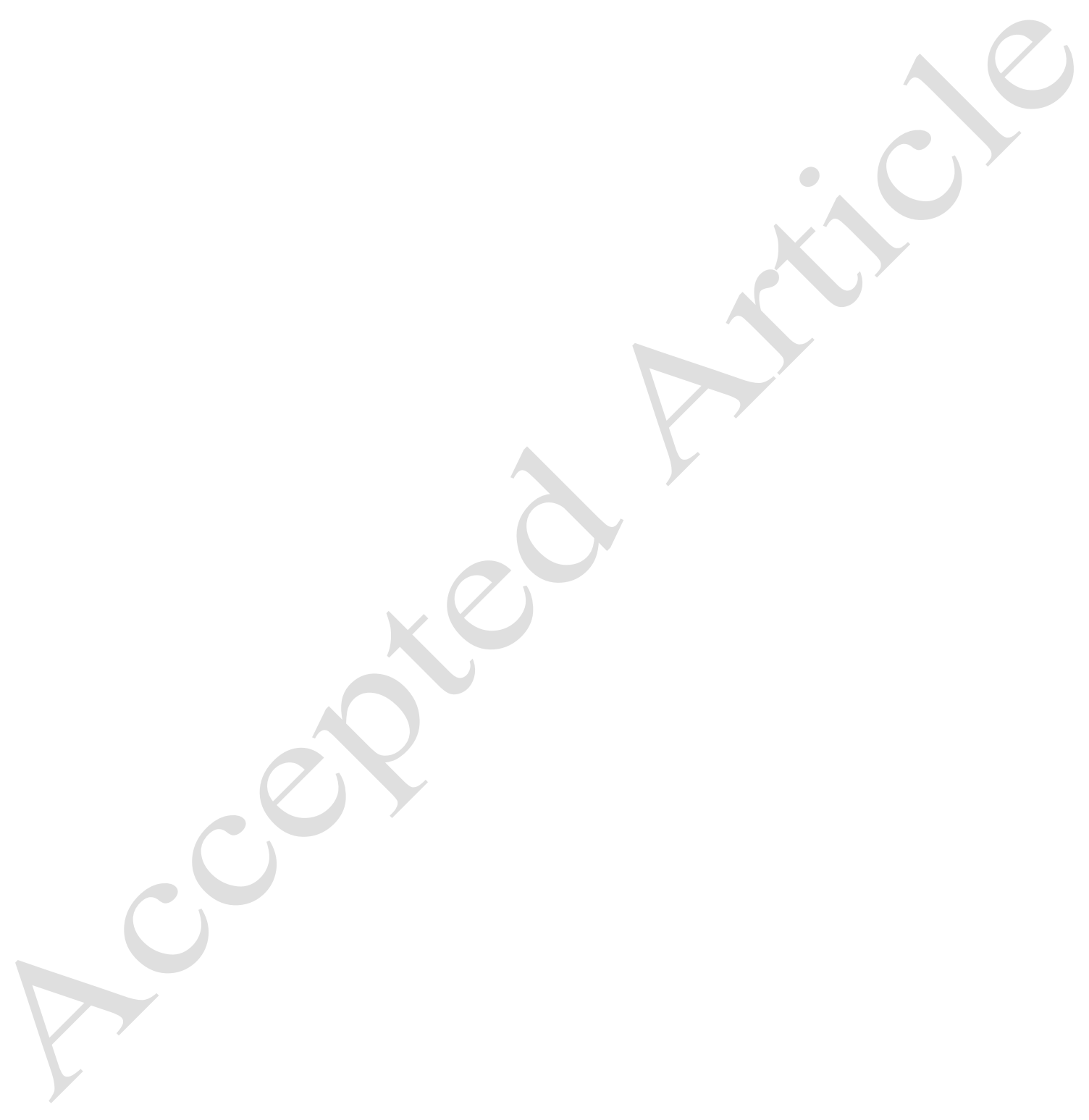

